
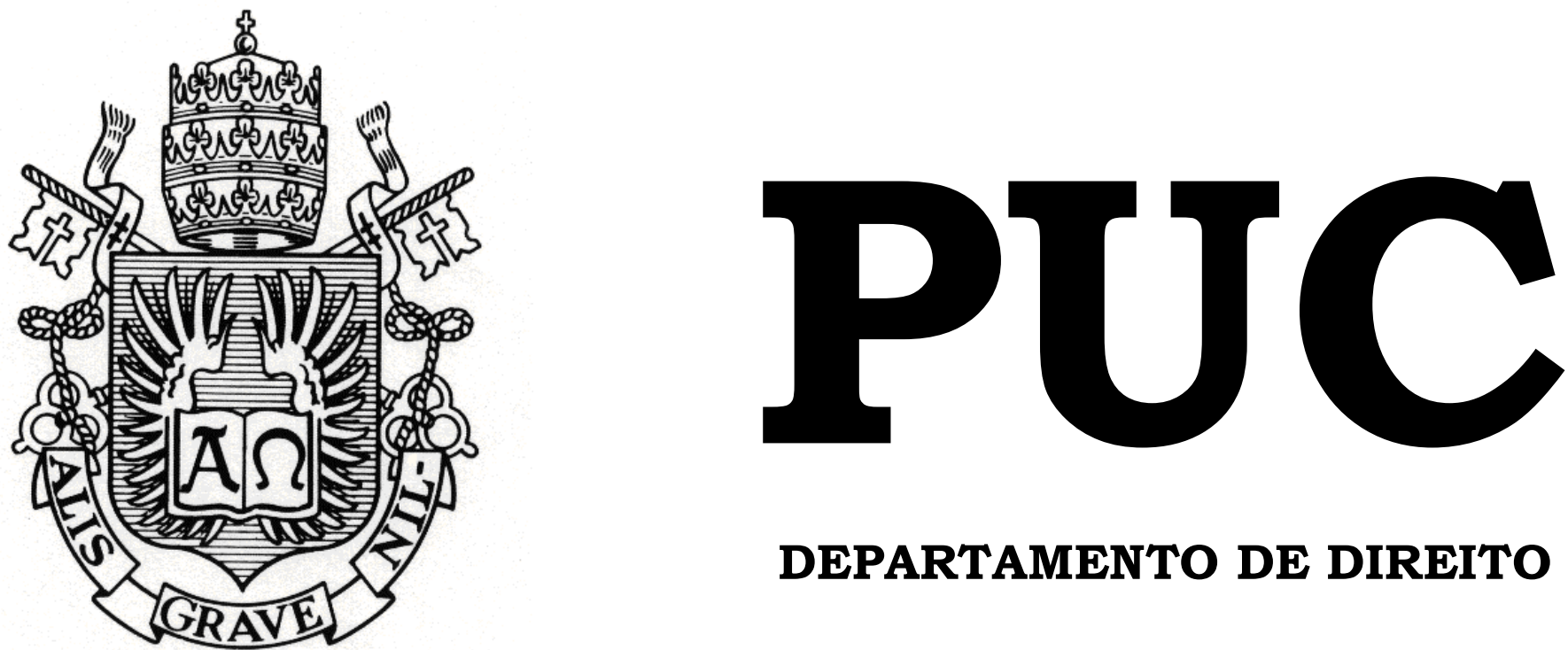

DEPARTAMENTO DE DIREITO

\title{
A EXPERIÊNCIA DOS TERMOS TERRITORIAIS COLETIVOS NA PROMOÇÃO DE MORADIA ACESSÍVEL E RESISTÊNCIA À MERCANTILIZAÇÃO DA TERRA
}

por

FELIPE CRUZ AKOS LITSEK

ORIENTADOR: Rafael da Mota Mendonça

2019.2

PONTIFÍCIA UNIVERSIDADE CATÓLICA DO RIO DE JANEIRO

RUA MARQUÊS DE SÃO VICENTE, 225 - CEP 22453-900

RIO DE JANEIRO - BRASIL 


\section{A EXPERIÊNCIA DOS TERMOS TERRITORIAIS COLETIVOS NA PROMOÇÃO DE MORADIA ACESSÍVEL E RESISTÊNCIA À MERCANTILIZAÇÃO DA TERRA}

por

\section{FELIPE CRUZ AKOS LITSEK}

Monografia

apresentada

ao

Departamento de Direito da Pontificia Universidade Católica do Rio de Janeiro (PUC-Rio) para a obtenção do Título de Bacharel em Direito.

Orientador(a): Rafael da Mota Mendonça 


\section{DEDICATÓRIA}

Dedico este trabalho a todas e todos que lutam pela Reforma Urbana, por uma nova forma de viver

e criar a cidade, uma forma que abrace todas as vivências, ideias, afetos e sonhos, e que construa uma cidade mais viva, diversificada, fraterna e, por que não, humana. 


\section{AGRADECIMENTOS}

Gostaria de agradecer, antes de tudo, à minha família pelo apoio e amor incondicional ao longo desta trajetória, sem o qual certamente não seria capaz de seguir num curso tão complexo como o Direito, o qual percorri numa oscilante relação de amor e ódio que ainda persiste até hoje. Um especial agradecimento à minha querida irmã e companheira de vida, Isabel, e à minha amada mãe, Paola e pai, Pedro.

À minhas avós tão queridas, Ana Lúcia e Maria Luiza, sempre curiosas e interessadas nos meus passos, e aos meus iluminados avôs, Álvaro e Akos, eternas referências de vida.

A todos que me acompanharam na trajetória da universidade, às amizades que tive a sorte de cultivar, tão verdadeiras e necessárias para a persistência nesta caminhada.

Ao grupo Terras e Lutas, que tive a sorte de encontrar logo no meu $3^{\circ}$ período e que me abriu os olhos para o potencial da universidade.

Ao PET-JUR, muito mais que um grupo de estudos, de formação.

Ao N.E.R.D.S., que estimulou em mim um interesse maravilhoso por filosofia e moral, tão importante na formação jurídica.

Ao NUTH, pelo seu incansável trabalho na defesa da moradia daqueles que mais necessitam, e pelo seu papel fundamental na luta pelo direito à cidade.

Por fim, agradeço imensamente a todos aqueles que tentam enxergar no direito alguma forma de mudança, os que não se contentam com a defesa cega da lei e da ordem, e os que lutam através do direito por um mundo mais justo e menos desigual. 


\section{RESUMO}

Este trabalho busca investigar um modelo de gestão do território e garantia de moradia acessível ainda inexistente no Brasil, mas comum em diversos outros lugares do mundo: o Termo Territorial Coletivo (TTC). É pretendido examinar este instrumento à luz dos processos de mercantilização do território no Brasil e no mundo, especialmente após o advento do novo marco legal nacional da regularização fundiária, a Lei 13.465/2017. Por fim, será feita uma observação acerca da aplicabilidade dos TTCs no contexto brasileiro, tendo em vista as profundas diferenças - sociais, econômicas, políticas e jurídicas - que o país possui em relação a outros lugares que adotam o modelo.

Palavras-chave: Direito à Moradia - Segurança da Posse - Termo Territorial Coletivo - Regularização Fundiária - Posse e Propriedade - Mercantilização da Terra - Núcleos Urbanos Informais 


\section{SUMÁRIO}

INTRODUÇÃ̃O

CAPÍTULO 1: DIREITO À MORADIA E SEGURANÇA DA POSSE ... 12

1.1 A Proteção Normativa do Direito à Moradia ............................................. 12

1.2 A Situação da (In)Segurança da Posse nas Cidades Brasileiras ................ 16

1.3 A Luta pela Reforma Urbana e a Política de Regularização Fundiária .... 22

1.4 Propriedade Privada como Modelo Regulatório: Um Movimento Global 28

CAPÍTULO 2: O TERMO TERRITORIAL COLETIVO 32

2.1 Origem e Evolução ................................................................................. 33

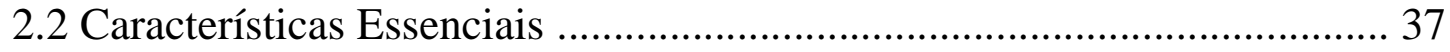

2.3 A Importação do Modelo para a Favela: o TTC Caño Martín Peña ......... 41

CAPÍTULO 3: A APLICABILIDADE DO TTC NO CONTEXTO

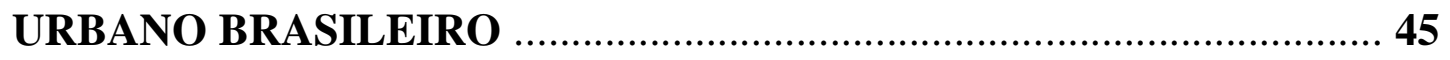

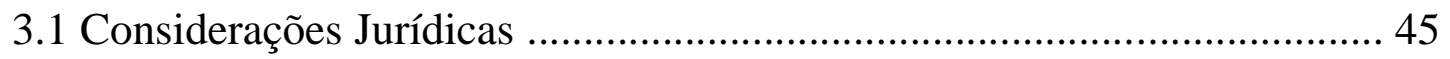

3.2 Considerações Materiais ........................................................................... 49

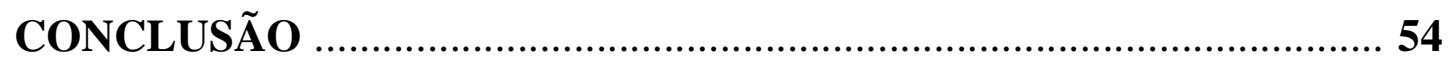

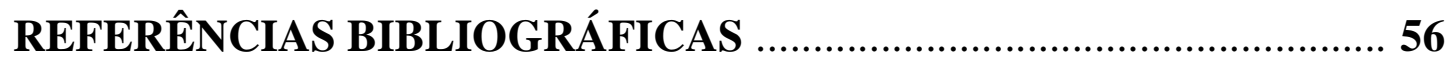




\section{LISTA DE ABREVIAÇÕES}

ADI: Ação Direta de Inconstitucionalidade

CDRU: Concessão de Direito Real de Uso

CLT: Community Land Trust

CRFB: Constituição da República Federativa do Brasil

CUEM: Concessão de Uso Especial para Fins de Moradia

FMI: Fundo Monetário Internacional

MP: Medida Provisória

NAU: Nova Agenda Urbana

ONU: Organização das Nações Unidas

PIDESC: Pacto dos Direitos Econômicos, Sociais e Culturais

ReUrb: Regularização Fundiária Urbana

TTC: Termo Territorial Coletivo

UN-Habitat: Programa das Nações Unidas para os Assentamentos Humanos 


\section{INTRODUÇÃO}

Desde 1948, com a promulgação da Declaração Universal de Direitos Humanos, a moradia é reconhecida como um direito humano fundamental, um elemento essencial de um padrão de vida digno, e requisito básico para o exercício dos demais direitos. Hoje, mais de 70 anos depois do advento da Declaração, ainda nos encontramos muito distantes de uma realidade em que este direito é plenamente assegurado. A promoção de moradia adequada para todos vem se apresentando como um dos maiores desafios da atualidade, desafio este que demanda uma atuação conjunta de inúmeros atores, como gestores públicos, movimentos sociais, parlamentares, urbanistas, pesquisadores, agências internacionais, e também operadores do direito.

Atualmente, a problemática da moradia não pode ser entendida de forma apartada da questão urbana. Vivemos em um mundo no qual 55\% da população vive em cidades ${ }^{1}$, ocupando um território de menos de 3\% da superfície terrestre (COX, 2010). Cidades concentram o maior volume do déficit habitacional, e é na realidade urbana onde nos deparamos com as maiores dificuldades de se garantir moradia acessível e adequada para todos. A desigualdade social, a segregação territorial, a primazia de interesses de setores da elite econômica no rumo das cidades, a falta de participação democrática na governança urbana, são todos problemas que afetam diretamente no acesso e proteção da moradia nas cidades do mundo. A luta pelo direito à moradia é também a luta pelo direito à cidade.

\footnotetext{
${ }^{1}$ Os dados são da ONU (2018 - ver referências). Segundo a agência, a expectativa é que, em 2050, cerca de $68 \%$ da população mundial passe a viver em cidades.
} 
$\mathrm{O}$ direito à moradia adequada não se resume à mera presença de um teto, mas compreende diversos outros elementos, como condições dignas de habitabilidade, presença de serviços básicos, custo acessível, preservação da identidade local e segurança da posse, ou seja, a estabilidade na permanência em seu local de moradia e proteção contra remoções forçadas. A segurança da posse requer que a relação jurídica entre uma pessoa e o espaço que ela ocupa seja reconhecida como legítima pelo Estado, conferindo a ela a proteção jurídica necessária para proteger seu direito à moradia contra tentativas de desalojamento.

O problema da irregularidade fundiária, marca sintomática das cidades do Brasil e em geral de toda a América Latina, é um grande obstáculo para a garantia de segurança da posse, e consequentemente da plena realização do direito à moradia. Sem direitos fundiários oficialmente reconhecidos, moradores de comunidades informais ficam vulneráveis a processos de remoção forçada por parte do Estado, e vêem limitadas suas possibilidades jurídicas de defesa. Diante disso, torna-se imperiosa uma política de regularização fundiária destes espaços, de forma a legalizar a relação dos residentes com o território ocupado, robustecendo a proteção jurídica na defesa da moradia ${ }^{2}$. Esta política deve reconhecer e valorizar a multiplicidade das formas de posse existentes na sociedade, adequando a legislação às situações concretas, de forma garantir segurança da posse de acordo com as práticas e identidades locais.

Existem diversas maneiras de possuir um pedaço de terra, no entanto, nos últimos 250 anos da história da relação entre a humanidade e o território por ela ocupado, uma forma muito específica de vínculo entre ser e espaço ganhou total hegemonia sobre as demais: a propriedade individual registrada (ROLNIK,

\footnotetext{
${ }^{2}$ Reconhecemos, no entanto, que a regularização fundiária engloba muito mais do que medidas voltadas para a questão dominial, de formalizar os direitos fundiários, e também inclui a chegada de equipamentos e serviços públicos essenciais, intervenções urbanísticas para melhoria de infraestrutura, medidas de preservação ambiental e de integração com a cidade, entre outras ações. Aqui adotamos o conceito de regularização fundiária plena, que vai muito além da questão do título de domínio, interferindo tanto na questão fundiária quanto na questão urbanística.
} 
2017, p. 8). A partir do século 18, em um processo que começa na Europa mas se expande rapidamente pelo mundo, a propriedade privada se torna o principal instituto jurídico que garante o domínio sobre a terra. Domínio este que não dependeria mais do exercício da posse direta do bem, mas simplesmente da existência de um título público que reconheça a figura do proprietário.

A hegemonia da propriedade sobre as demais formas de posse foi um passo essencial para a consolidação do processo de mercantilização da terra, isto é, de conversão de seu valor de uso (sua utilidade, finalidade a que ela atende), em seu valor de troca (valor enquanto mercadoria). Este movimento traz consequências imensas para o direito à moradia, já que abre portas para que a terra seja afastada de sua finalidade social de assegurar um direito fundamental para seu potencial mercadológico de gerar renda. O fenômeno descrito é particularmente grave em grandes metrópoles, submetidas a um processo constante de valorização imobiliária, cujo resultado é a incapacidade das camadas mais pobres de acessarem formalmente a terra.

Cada vez mais, políticas de regularização fundiária vêm adotando a propriedade individual como paradigma regulatório de territórios informais. Este fenômeno, de amplitude global, é evidenciado no Brasil com a chegada da Lei 13.465/2017, novo marco jurídico nacional da regularização fundiária. A nova lei privilegia a titulação individual via transferência de propriedade como norte da política regulatória, o que pode abrir novas portas para o processo de mercantilização da terra urbana e permitir que territórios antes inacessíveis sejam incorporados pelo mercado imobiliário, em sua busca incessante por novos espaços. Paradoxalmente, este modelo de regularização fundiária pode acabar aumentando a insegurança da posse, na medida em que estimula uma outra forma de despossessão, não causada pela ação estatal e pela irregularidade, mas sim pela pressão mercadológica sobre os territórios populares especialmente os localizados em áreas nobres da cidade. 
Diante deste cenário ambíguo, na qual tanto a irregularidade quanto a presença de um título de propriedade podem ameaçar a permanência de comunidades em seus espaços, torna-se necessário investigar formas alternativas de relação com o território, que busquem impedir a mercantilização da terra e ao mesmo tempo garantir segurança da posse aos seus ocupantes, visando a plena realização do direito à moradia. Uma destas formas é o tema desta monografia: o Termo Territorial Coletivo (TTC).

O Termo Territorial Coletivo - em inglês: Community Land Trust - é um modelo de gestão coletiva da terra nascido nos Estados Unidos nos anos 60 e depois disseminado por todo o planeta. Ele busca afirmar a terra como um bem comum de todos seus residentes, retirando-a do mercado imobiliário e atrelandoa à sua finalidade social de garantir habitação. Seu objetivo central é a promoção de moradia acessível economicamente de forma permanente.

Apesar de estar bastante consolidado no mundo e presente em diversos países, o Termo Territorial Coletivo ainda é bastante desconhecido no Brasil. Na verdade, em toda a América Latina há apenas uma experiência de um TTC em funcionamento, que está na capital de Porto Rico, San Juan. A escolha pelo estudo de um instrumento inexistente no direito brasileiro se deu pela percepção de que a difícil situação atual da regularização fundiária e proteção do direito à moradia no Brasil poderia se beneficiar profundamente de novas e promissoras experiências. Estamos imersos na desilusão, na falta de fé no futuro, desgraçadamente acostumados a tecer críticas das mais sofisticadas aos problemas que no rodeiam, mas incapazes de enxergar alternativas concretas, proposições criativas, possíveis saídas desse labirinto.

Esta monografia está dividida em três partes. Na primeira, será feita uma introdução ao direito à moradia e à problemática da segurança da posse. Examinaremos a efetivação deste direito no Brasil e as políticas de regularização fundiária dos territórios informais. Na segunda, apresentaremos o Termo Territorial Coletivo, sua origem, histórico e características essenciais. 
Abordaremos a experiência de Porto Rico como um caso paradigma do único TTC existente na América Latina. Por fim, na terceira parte serão tecidas algumas considerações sobre a aplicabilidade do Termo Territorial Coletivo no Brasil: seu potencial, desafios e alguns obstáculos para sua implementação.

$\mathrm{O}$ objeto central deste trabalho é o direito à moradia. A casa, o lar, esta figura que transcende a existência física, e é também cultura, identidade, afeto e comunidade. Talvez a pergunta central que permeia estas folhas é: como assegurar a plena realização do direito à moradia, em um mundo no qual a terra é convertida em mercadoria? Longe de apresentar uma resposta definitiva, apenas navegamos em possibilidades, caminhos novos e misteriosos, experiências criativas e potentes. Oxalá com elas poderemos contribuir com algo para aquela que é a luta mais fundamental, mais elementar: a luta pela terra. 


\section{CAPÍTULO 1 - DIREITO À MORADIA E SEGURANÇA DA POSSE}

\subsection{A Proteção Normativa do Direito à Moradia}

A partir de meados do século $\mathrm{XX}$, o direito à moradia inicia um longo processo de reconhecimento e proteção dentro do campo jurídico, nacional e internacional. $\mathrm{O}$ movimento parte de uma profunda mudança de paradigma normativo, na qual passam a ser positivados direitos que exigem não só uma resposta negativa por parte dos poderes constituídos - bastando uma mera abstenção de gerar uma violação - mas também, e principalmente, uma postura positiva, que demanda ações concretas para garantir a própria existência do direito, como é o caso da moradia. O ponto de partida deste processo é a Declaração de Direitos Humanos da ONU, de 1948, que eleva a moradia à categoria de um direito humano fundamental ${ }^{3}$.

O texto da Declaração Universal estabelece um padrão de vida mínimo como direito de todos os seres humanos, sendo a moradia um requisito essencial deste padrão. Dentro da lógica da declaração, a moradia está enquadrada no grupo dos direitos econômicos, sociais e culturais (ao lado da alimentação, trabalho, lazer, educação, etc.), em contraponto ao grupo dos direitos civis e políticos (vida, liberdade de crença, direito ao voto, liberdade de expressão, etc.). Apesar de tal divisão normativa, há que se ter claro que entre direitos humanos não há hierarquia, mas sim uma relação de interdependência e indivisibilidade, de forma que "a garantia dos direitos civis e políticos é condição para a garantia

\footnotetext{
${ }^{3}$ Declaração Universal de Direitos Humanos da ONU. Art. XXV: Todo ser humano tem direito a um padrão de vida capaz de assegurar-lhe, e a sua família, saúde e bem-estar, inclusive alimentação, vestuário, habitação, cuidados médicos e os serviços sociais indispensáveis, e direito à segurança em caso de desemprego, doença, invalidez, viuvez, velhice ou outros casos de perda dos meios de subsistência em circunstâncias fora de seu controle.
} 
dos direitos sociais, econômicos e culturais e vice-versa. Quando um deles é violado, os demais também o são." (PIOVESAN, 2008, p. 10, cit in ABREU, 2011, p. 394). Desta forma, a partir da Declaração de 1948, a moradia passa a ocupar um lugar fundamental dentro da doutrina de proteção dos direitos humanos, compreendida como um requisito básico para o exercício dos demais direitos, e um elemento essencial para um padrão de vida digno.

Ainda no campo internacional, merece um destaque central o Pacto Internacional de Direitos Econômicos, Sociais e Culturais (PIDESC), de 1966, que versa sobre o direito à moradia em seu artigo 11:

Os Estados Partes do presente Pacto reconhecem o direito de toda pessoa a um nível de vida adequado para si próprio e sua família, inclusive à alimentação, vestimenta e moradia adequadas, assim como a uma melhoria contínua de suas condições de vida. Os Estados Partes tomarão medidas apropriadas para assegurar a consecução desse direito, reconhecendo, nesse sentido, a importância essencial da cooperação internacional fundada no livre consentimento.

É possível observar que o PIDESC vai além da Declaração Universal e afirma expressamente a obrigação dos Estados a garantirem a efetivação deste direito. Aquilo que aparentava possuir mera natureza declaratória agora ganha força inequívoca de uma disposição normativa, impondo claras contrapartidas por parte das nações signatárias. Além disso, o pacto traz a necessidade da cooperação internacional para o alcance de seus objetivos, e também trabalha a ideia de uma realização progressiva deste direito, que deve ser perseguida de forma permanente. No Brasil, o PIDESC foi internalizado somente no ano de 1992, através do Decreto ${ }^{\circ}$ 591/1992, introduzindo pela primeira vez de forma expressa a moradia dentro de nosso ordenamento jurídico.

No Brasil, o direito à moradia apenas ganha explicitamente status constitucional no ano 2000, com o advento da Emenda à Constituição ${ }^{\circ}$ $26 / 2000$, que insere a moradia dentro do leque dos direitos sociais previstos no 
Art. $6^{\circ}$ da Carta Maior ${ }^{4}$. Apesar disso, mesmo antes desta introdução, diversos autores já defendiam a existência de uma proteção implícita do direito à moradia dentro do texto constitucional (SAULE Jr, 1997), extraída de normas como a função social da propriedade (Art. $5^{\circ}, \mathrm{XXIII)}$ ), necessidade do salário mínimo atender despesas com a moradia (Art. $7^{\circ}, \mathrm{IV}$ ), usucapião especial urbana (Art. 183), entre outras. A partir de 2000, no entanto, com a introdução expressa do direito à moradia na Constituição, quaisquer divergências doutrinárias que ainda haveriam de existir são extintas: moradia é um direito fundamental de todos exigível, portanto, perante o Estado. Neste sentido, nos lembra Nelson Saule que:

O direito à moradia como integrante da categoria dos direitos econômicos, sociais e culturais, para ter eficácia jurídica e social, pressupõe a ação positiva do Estado, através de execução de políticas públicas, no caso em especial da promoção da política urbana e habitacional (1997, p. 69)

A despeito desta longa trajetória normativa ter consolidado o direito à moradia como prerrogativa básica de todo ser humano e determinado a obrigação jurídica dos Estados em garanti-lo, ainda nos deparamos com um sério obstáculo: o que é o direito à moradia? Assim como sofrem todos os demais direitos humanos, o elevado grau de abstrativização que eles possuem - devido a sua pretensão de se tornarem universalizantes - ameaça esvaziar seu conteúdo por completo. No caso da moradia, este efeito é particularmente grave, afinal, a mera existência de um teto e quatro paredes não pode ser suficiente para responder esta pergunta.

Neste ponto, é imprescindível mencionar o Comentário Geral $n^{\circ} 4$ do Comitê de Direitos Econômicos, Sociais e Culturais da ONU (1991), que interpreta o artigo 11 do PIDESC e estabelece o conteúdo do direito à moradia.

\footnotetext{
${ }^{4}$ CF/88 Art. $6^{\circ}$ : São direitos sociais a educação, a saúde, o trabalho, a moradia, o lazer, a segurança, a previdência social, a proteção à maternidade e à infância, a assistência aos desamparados, na forma desta Constituição.
} 
O comentário traz uma concepção ampla de moradia adequada, um conceito que vai muito além da existência concreta de um alojamento:

$\mathrm{Na}$ opinião do Comitê, o direito ao alojamento não deve entender-se em sentido restrito. Não se trata aqui de proporcionar um simples teto a servir de abrigo ou de considerar o direito ao alojamento exclusivamente como um bem. Pelo contrário, deve ser visto como o direito a um lugar onde seja possível viver em segurança, em paz e com dignidade. (p. 111)

Segundo o documento, existem diversos elementos que devem ser observados para que seja assegurado o direito à moradia adequada. São eles: (i) disponibilidade de serviços e infra-estruturas: a residência deve dispor das estruturas essenciais à saúde, conforto, higiene, segurança; (ii) acessibilidade: os custos da moradia não podem comprometer a satisfação das demais necessidades básicas; (iii) habitabilidade: o espaço da habitação deve ser capaz de proteger a integridade de seus moradores; (iv) facilidade de acesso: a residência deve ser acessível para grupos vulneráveis, como idosos ou deficientes; (v) localização: proximidade e integração com o local de emprego, comércio, espaços de lazer, hospitais, etc; (vi) respeito pelo meio cultural: o local de moradia deve refletir as diversidades culturais e identitárias presentes em cada comunidade e, por fim; (vii) segurança legal da ocupação: um conceito que chamaremos aqui de segurança da posse.

A segurança da posse é um aspecto fundamental do direito à moradia adequada. $\mathrm{O}$ conceito diz respeito à garantia que um morador ou comunidade tem de permanecer em seu lugar de residência, gozando de segurança jurídica e proteção contra qualquer tipo de remoção forçada. A perspectiva de permanência no lar é o que permite a construção de um futuro, a busca por melhorias nas condições de habitabilidade, a formação identidades locais e redes de solidariedade, e o desenvolvimento comunitário.

Para haver segurança na posse, é preciso que a relação jurídica do morador com seu território seja reconhecida pelo Estado como legítima. A irregularidade fundiária é um dos principais obstáculos para a garantia da 
segurança da posse, pois submete comunidades inteiras a uma situação de ameaça constante de remoção pelo Poder Público, limitando suas possibilidades jurídicas de defesa. Sem direitos fundiários reconhecidos, moradores se tornam vulneráveis a processos de desalojamento forçado, movidos pelo próprio Estado ou por particularidades, o que afronta diretamente seu direito à moradia.

No entanto, não é só a irregularidade fundiária que gera insegurança da posse. Outros fenômenos podem ser igualmente perigosos neste sentido. Processos de valorização imobiliária e a influência de instituições financeiras e grandes conglomerados econômicos também podem estimular uma outra forma de remoção forçada, causada pelo aumento dos custos de vida ou pressão para a venda dos imóveis. Este fenômeno, chamado de "remoção branca" ou expulsão pelo mercado, afeta de forma mais violenta os territórios populares principalmente os localizados em áreas nobres da cidade - e força famílias de baixa renda a se mudarem para locais periféricos, formando cidades cada vez mais segregadas.

Apesar da já consolidada proteção normativa do direito à moradia no Brasil e no mundo, ainda vivemos uma realidade muito distante da plena satisfação deste direito. A promoção de moradia adequada para todos vem se apresentando como um dos maiores desafios da atualidade, em um planeta cada vez mais populoso e urbanizado. A seguir, faremos um breve exame do atual cenário do direito à moradia no Brasil.

\subsection{A Situação da (In)Segurança da Posse no Brasil}

Segundo dados da Fundação João Pinheiro, em levantamento realizado em 2015, o déficit habitacional no Brasil é de 6,355 milhões de unidades (87\% em área urbana), no Estado do RJ, de 460.785 domicílios, e na cidade do Rio de Janeiro, de 340.083 domicílios (FUNDAÇÃO JOÃO PINHEIRO, 2018, p. 33). A região Sudeste é a que mais sofre com o déficit habitacional, concentrando 
39\% do total levantado (p. 31). A metodologia para o cálculo do déficit foi importada de outro levantamento feito em 2010, e não inclui apenas famílias sem-teto, mas engloba uma série de outros aspectos da moradia:

O déficit habitacional é calculado como a soma de quatro componentes: domicílios precários (soma dos domicílios improvisados e dos rústicos), coabitação familiar (soma dos cômodos e das famílias conviventes secundárias com intenção de constituir um domicílio exclusivo), ônus excessivo com aluguel urbano e adensamento excessivo de domicílios alugados. (FUNDAÇÃO JOÃO PINHEIRO, 2013, p. 14)

Ainda de acordo com o estudo, o Brasil possui 7,906 milhões de domicílios vagos, dos quais $80 \%$ se encontram em área urbana (p. 37). Destes, 6,893 milhões estão em condições de serem ocupados, e os demais estão em construção ou reforma. Assim como no déficit, do total de domicílios vagos, 39\% se encontram na região Sudeste do país (p. 39). Estes são imóveis que se encontram abandonados por seus proprietários, ou parados, em busca de compradores, locatários, ou simplesmente submetidos a processos de especulação imobiliária, de forma a permitir que o proprietário aufira lucro sobre uma eventual valorização da terra, sem dar nenhuma função social ao bem.

Outra informação valiosa que traz o estudo diz respeito aos aspectos da moradia que levam ao déficit. Segundo ele, o ônus excessivo com aluguel corresponde a metade do déficit habitacional no país ${ }^{5}$ (p. 41), sendo que, na cidade do Rio de Janeiro, este componente chega a 66\% do déficit habitacional (p. 45). A metodologia adotada pelo estudo considera ônus excessivo de aluguel o gasto de mais de $30 \%$ da renda familiar com o aluguel da casa, para famílias cuja renda é de até 3 salários mínimos (p. 23). O custo da moradia é um fator que precisa ser levado em conta na discussão sobre direito à moradia adequada, pois não pode o ônus com a habitação prejudicar a satisfação das demais necessidades básicas.

\footnotetext{
${ }^{5}$ Em relação aos outros fatores, a coabitação familiar representa $29,9 \%$ do déficit, as habitações precárias: $14,8 \%$ e o adensamento excessivo dos domicílios alugados: 5,2\% (FUNDAÇÃO JOÃO PINHEIRO, 2018, p. 40)
} 
A ampla metodologia utilizada pela Fundação no cálculo do déficit faz com que seu exame da questão habitacional se aproxime dos requisitos da ONU para uma moradia adequada, que não se limitam à mera existência de um alojamento, mas também se atentam para a necessidade da moradia assegurar conforto, dignidade e proteção aos seus residentes, bem como o pleno exercício dos demais direitos. No entanto, um elemento fundamental da moradia não é levada em consideração na aferição do déficit: a segurança da posse.

Dados sobre a situação de irregularidade fundiária no Brasil ainda são bastante precários, e a dificuldade de se colher informações a respeito é um enorme óbice ao pleno conhecimento da questão da moradia e da segurança da posse no país. No entanto, é um consenso entre pesquisadores do tema que vivemos em um país marcado por uma situação generalizada de irregularidades fundiárias e urbanísticas, uma marca histórica das cidades brasileiras. O Ministério do Desenvolvimento, por exemplo, estimou este ano que cerca de 50\% dos imóveis no país são irregulares, do ponto de vista do não-cumprimento das regulações urbanísticas ou da ausência de escritura formal (RIBEIRO, 2019). A mesma cifra é mencionada por Rosângela Luft, professora e pesquisadora especializada em direito urbanístico e planejamento urbano, em palestra sobre regularização fundiária e direito da cidade (EMERJ, 2017).

Os motivos que ensejaram esta situação de generalizada irregularidade fundiária são históricos, e remetem à própria formação territorial do Brasil. Uma análise mais aprofundada sobre as causas que levaram a esta realidade foge ao escopo deste trabalho, mas ainda assim é preciso traçar algumas considerações, a começar pontuando que a irregularidade não é uma escolha, mas sim o resultado de um processo histórico de exclusão da classe trabalhadora do acesso formal à terra. Este processo é intensificado pela ascensão de uma forma jurídica de relação com o território que se tornou hegemônica em relação às demais: a propriedade. 
A consolidação de um modelo jurídico proprietário no Brasil tem como seu marco histórico inicial a promulgação da Lei $n^{\circ}$ 601/1850 do Império, a chamada Lei de Terras (ABREU, 2014, p. 220). Esta lei institui a compra e venda como a única via legítima de aquisição das terras disponíveis, bem como criminaliza qualquer outra forma de acesso à terra ${ }^{6}$. Além de estimular a conversão da terra em mercadoria, a lei exclui uma camada imensa de trabalhadores da possibilidade de ter sua posse legitimada, já que apenas uma parcela mínima da população possui recursos para participar do mercado formal de terras que começava a se desenvolver no país. Não é coincidência que esta lei antecipa em poucas décadas o fim da escravidão no Brasil, sepultando qualquer possibilidade de acesso à terra por parte dos trabalhadores escravizados, que depois se tornariam trabalhadores assalariados (GADELHA, 1989).

A partir da Lei de Terras de 1850, ser "dono" da terra passa a significar ter o título jurídico de propriedade, adquirido através da compra, e independente de qualquer relação de posse efetiva do território. Na medida em que apenas a existência de um título torna legal a ocupação da terra, todas as demais formas de acesso à terra tornam-se ilegais, criminosas, desprovidas de proteção jurídica. Temos, portanto, um processo no qual a condição de ilegalidade das camadas populares é produzida a partir de uma escolha legislativa que privilegia as elites fundiárias, fazendo com que a dicotomia proprietários/não-proprietários se torne uma das grandes fontes de produção de desigualdade no Brasil:

O problema desse modelo jurídico proprietário de apropriação e ocupação do território brasileiro não está, propriamente, no instituto da propriedade, cuja importância não questionamos; mas sim num exclusivismo proprietário, que é a marca do modelo e relega a posse (o poder de fato sobre a terra) ao irremediável plano da ilegalidade/criminalidade quando não consentida, direta ou indiretamente, pelo proprietário, ainda que o detentor do poder de fato sobre a terra (urbana ou rural) nela

\footnotetext{
${ }^{6}$ Lei $n^{\circ} 601 / 1850$. Art. $1^{\circ}$ Ficam prohibidas as acquisições de terras devolutas por outro titulo que não seja o de compra.

Art. $2^{\circ}$ Os que se apossarem de terras devolutas ou de alheias, e nellas derribarem mattos ou thes puzerem fogo, serão obrigados a despejo, com perda de bemfeitorias, e de mais soffrerão a pena de dous a seis mezes do prisão e multa de $100 \$$, além da satisfação do damno causado. Esta pena, porém, não terá logar nos actos possessorios entre heréos confinantes.
} 
trabalhe ou institua sua moradia e a de sua família. Posse legítima seria aquela de algum modo consentida pelo proprietário: através do aluguel, do usufruto, do arrendamento, da cessão de uso, etc. (ABREU, 2014, p. 223)

Desta forma, é introduzida em nosso sistema jurídico a ideia de que a única forma legítima de acesso à terra - e consequentemente, à moradia - é a propriedade em si, ou a posse derivada da propriedade (aluguel, arrendamento, cessão de uso, usufruto, etc). Esta dogmática jurídica, que submete a posse a uma relação de subalternidade com a propriedade, ainda está bastante presente no pensamento de nossos juízes e Tribunais, e é um dos maiores obstáculos à plena realização do direito à moradia atualmente, pois ameaça constantemente a segurança da posse dos não-proprietários.

Diante da incapacidade de acessar formalmente a terra no meio rural, e atendendo a uma demanda incessante por mão de obra nas cidades que cresciam em ritmo acelerado, boa parte dos trabalhadores do campo migraram para o meio urbano, se deparando novamente com o mesmo problema: a incapacidade de acessar o mercado imobiliário formal. Por conta disso, muitos são levados a estabelecerem sua moradia em áreas sem escritura, terras públicas ou privadas, regiões de difícil acesso ou que contrariam regulações urbanísticas de loteamento.

Assim surgem os chamados assentamentos informais, espaços que se desenvolvem sob uma lógica própria de construção, uso do solo e relação possessória com a terra, e que possuem uma relação conturbada e ambígua com o Estado: por vezes de tolerância e anuência, por vezes de repressão. Tratam-se, nas palavras de Raquel Rolnik, de:

[...] zonas de indeterminação entre legal/ilegal, planejado/não-planejado, formal/informal, dentro/fora do mercado, presença/ausência do Estado. Tais indeterminações são os mecanismos por meio dos quais se constrói a situação de permanente transitoriedade, a existência de um vasto território de reserva, capaz de ser capturado "no momento certo". (2018, p. 174)

Pelo fato de haverem se constituído à margem do modelo jurídico proprietário descrito anteriormente, são espaços considerados irregulares sob a 
ótica da ordem jurídica dominante, e, portanto, submetidos a uma situação de insegurança constante.

Ameaças de remoção forçada de moradores de comunidades informais ou outras ocupações irregulares são desgraçadamente comuns em nosso cotidiano $^{7}$. Estas ameaças se concretizam através de intervenções diretas por parte do Poder Executivo (executando intervenções urbanísticas ou simplesmente se utilizando de seu poder de polícia), ou através do próprio Judiciário, no julgamento de ações civis públicas, reintegrações de posse, reivindicatórias de propriedade, entre outras. Tratam-se de processos que, como lembra Abreu (2011, p. 402) muitas vezes "os moradores diretamente afetados pela questão sob judice, os assentados, simplesmente não são chamados a participar do processo judicial [...]". No entanto, mesmo quando o são, o não reconhecimento oficial dos direitos fundiários destes moradores reduzem drasticamente suas possibilidades jurídicas de defesa, frente ao já consolidado complexo normativo de proteção da propriedade.

Apesar da ascensão, desde o século passado, de uma forte rede de proteção normativa do direito à moradia, tanto no plano nacional quanto no internacional, a realidade concreta da efetivação deste direito ainda se encontra bastante distante no Brasil. Um dos motivos para isto é a consolidação de um sistema jurídico-burguês que absolutiza a propriedade diante de qualquer outra forma de relação com o território, tornando-as vulneráveis e desprovidas de proteção jurídica. A partir da hegemonia da propriedade, as demais formas de acesso à moradia são consideradas "irregulares", submetidas a uma situação de insegurança permanente, com a ameaça de remoção sempre à espreita.

\footnotetext{
${ }^{7}$ Para ilustrar esta realidade, toma-se como exemplo o caso de Altair Guimarães, morador do Rio de Janeiro: aos 14 anos, quando vivia na comunidade da ilha dos Caiçaras (no entorno da Lagoa Rodrigo de Freitas), sofreu sua primeira remoção, sendo reassentado na Cidade de Deus. Décadas depois, já casado e com filhos, enfrenta um novo processo de remoção, por decorrência da construção da Linha Amarela, que o força a se mudar mais uma vez. Sem alternativas, foi se instalar na Vila Autódromo, onde sofreu o terceiro processo de remoção de sua vida, por conta da celebração dos Jogos Olímpicos (BARROS, 2013). O exemplo parece ilustrar bem a condição de "transitoriedade permanente" mencionada por Rolnik, na qual a perspectiva de permanência no lar é praticamente nula.
} 
Idealmente, a defesa da moradia deveria superar esta dicotomia regularidade/irregularidade, e se apresentar com a força normativa que de fato possui: a de um direito humano fundamental, que deve ser assegurado independente da situação fundiária na qual a moradia está inserida. No entanto, na medida em que a irregularidade fundiária apresenta uma ameaça à segurança da posse - e portanto ao próprio direito à moradia - torna-se necessário corrigir esta situação de irregularidade, através de uma efetiva política de regularização fundiária.

\subsection{A Luta pela Reforma Urbana e a Política de Regularização Fundiária}

Como vimos, a segurança da posse é um aspecto fundamental do direito à moradia adequada, e a generalizada situação de irregularidade fundiária no Brasil desafia a plena satisfação deste direito. Diante deste cenário, é obrigação do Estado promover uma política de regularização fundiária dos assentamentos informais, garantindo direitos fundiários e proteção jurídica contra tentativas de remoção. São diversos os modelos e instrumentos de regularização fundiária possíveis, e a escolha de qual deles é o mais adequado é eminentemente política, e atende a interesses distintos.

Antes de adentrarmos na análise da regularização fundiária no Brasil, no entanto, é preciso traçar um breve panorama da evolução dos institutos urbanísticos nos últimos anos, resultado da pressão e luta dos movimentos pelo direito à cidade. Este estudo é importante para entendermos como se deu o desenvolvimento do direito urbanístico no Brasil desde a constituinte, um movimento que vai influenciar diretamente na política de regularização fundiária dos assentamentos informais adotada pelo Estado.

A luta pela reforma urbana e pelo direito à moradia no Brasil obteve diversas conquistas nas últimas décadas no campo jurídico - constitucional. A 
começar pelo tratamento dado pela Constituição Federal de 1988 à questão urbana, que positiva conceitos importantes como a função social da propriedade urbana e as funções sociais da cidade, além de impor a obrigatoriedade do Plano Diretor para municípios acima de 20.000 habitantes e criar a figura da usucapião especial urbana ${ }^{8}$.

No campo infraconstitucional, merece especial menção o Estatuto da Cidade (Lei 10.257/2001), que regulamenta os artigos 182 e 183 da Constituição, estabelecendo metas, princípios e instrumentos para assegurar o cumprimento das funções sociais da cidade, sempre visando a efetivação do direito à moradia. Dentre estes, ressalta-se a Concessão de Direito Real de Uso $(\mathrm{CDRU})^{9}$, figura jurídica antiga que visa garantir o direito de uso da terra em

${ }^{8}$ CRFB/88. Título IV. Capítulo II. Da Política Urbana.

Art. 182. A política de desenvolvimento urbano, executada pelo Poder Público municipal, conforme diretrizes gerais fixadas em lei, tem por objetivo ordenar o pleno desenvolvimento das funções sociais da cidade e garantir o bem- estar de seus habitantes.

$\S 1^{\circ} \mathrm{O}$ plano diretor, aprovado pela Câmara Municipal, obrigatório para cidades com mais de vinte mil habitantes, é o instrumento básico da política de desenvolvimento e de expansão urbana.

$\S 2^{\circ} \mathrm{A}$ propriedade urbana cumpre sua função social quando atende às exigências fundamentais de ordenação da cidade expressas no plano diretor. dinheiro.

$\S 3^{\circ}$ As desapropriações de imóveis urbanos serão feitas com prévia e justa indenização em

$\S 4^{\circ}$ É facultado ao Poder Público municipal, mediante lei específica para área incluída no plano diretor, exigir, nos termos da lei federal, do proprietário do solo urbano não edificado, subutilizado ou não utilizado, que promova seu adequado aproveitamento, sob pena, sucessivamente, de:

I - parcelamento ou edificação compulsórios;

II - imposto sobre a propriedade predial e territorial urbana progressivo no tempo;

III - desapropriação com pagamento mediante títulos da dívida pública de emissão previamente aprovada pelo Senado Federal, com prazo de resgate de até dez anos, em parcelas anuais, iguais e sucessivas, assegurados o valor real da indenização e os juros legais.

Art. 183. Aquele que possuir como sua área urbana de até duzentos e cinqüenta metros quadrados, por cinco anos, ininterruptamente e sem oposição, utilizando-a para sua moradia ou de sua família, adquirir-lhe-á o domínio, desde que não seja proprietário de outro imóvel urbano ou rural.

$\S 1^{\circ} \mathrm{O}$ título de domínio e a concessão de uso serão conferidos ao homem ou à mulher, ou a ambos, independentemente do estado civil.

$\S 2^{\circ}$ Esse direito não será reconhecido ao mesmo possuidor mais de uma vez.

$\S 3^{\circ}$ Os imóveis públicos não serão adquiridos por usucapião.

${ }^{9}$ Dec. 271/1967. Art. 70 É instituída a concessão de uso de terrenos públicos ou particulares remunerada ou gratuita, por tempo certo ou indeterminado, como direito real resolúvel, para fins específicos de regularização fundiária de interesse social, urbanização, industrialização, edificação, cultivo da terra, aproveitamento sustentável das várzeas, preservação das comunidades tradicionais e seus meios de subsistência ou outras modalidades de interesse social em áreas urbanas. (Redação dada pela Lei 11.481/2007). 
situações possessórias de interesse social, elencada como instrumento de regularização fundiária pelo Estatuto da Cidade. Outro marco importante foi o advento da Medida Provisória n 2.220/2001, que cria a figura da Concessão de Uso Especial para Fins de Moradia (CUEM) ${ }^{10}$, reconhecendo a posse em áreas públicas, desde que utilizada para a moradia, e garantindo o direito à permanência no local. Apesar do forte avanço progressista no campo jurídico, fruto da luta de movimentos sociais urbanos, é necessário ressaltar o caráter exclusivamente "juridicista" destas vitórias, longe de significar avanços na realidade concreta:

Os movimentos sociais devem lutar por novos marcos jurídicos, mas devem considerar que isso está muito longe de assegurar conquistas reais. Estamos testemunhando a aplicação quase nula dos instrumentos mais importantes do Estatuto da Cidade, seis anos após sua promulgação. Apesar da força e da unidade dos movimentos urbanos, o secularmente almejado acesso à terra pouco avançou concretamente nesses anos de conquistas institucionais. Conservar os pobres na ilegalidade, quando ela mesma se apropriou ilegalmente da maior parte do patrimônio em terras públicas, parece ser o ponto de honra da elite brasileira. (MARICATO, 2011, p. 95-96)

No tocante à política de regularização fundiária, é preciso destacar a Lei 11.977/2009, que criou o programa Minha Casa Minha Vida e instituiu pela primeira vez um marco jurídico federal sobre a regularização fundiária de assentamentos urbanos (Capítulo III da lei), definindo seu conceito:

Art. 46. A regularização fundiária consiste no conjunto de medidas jurídicas, urbanísticas, ambientais e sociais que visam à regularização de assentamentos irregulares e à titulação de seus ocupantes, de modo a garantir o direito social à moradia, o pleno desenvolvimento das funções sociais da propriedade urbana e o direito ao meio ambiente ecologicamente equilibrado. (Artigo revogado pela Lei $13.465 / 2017)$

De cara, observa-se que a lei adota o conceito de regularização fundiária plena, um processo que vai muito além da questão dominial, e que também

\footnotetext{
${ }^{10}$ MP 2.220/2001. Art. 1o Aquele que, até 22 de dezembro de 2016, possuiu como seu, por cinco anos, ininterruptamente e sem oposição, até duzentos e cinquenta metros quadrados de imóvel público situado em área com características e finalidade urbanas, e que o utilize para sua moradia ou de sua família, tem o direito à concessão de uso especial para fins de moradia em relação ao bem objeto da posse, desde que não seja proprietário ou concessionário, a qualquer título, de outro imóvel urbano ou rural. (Redação dada pela Lei 13.465/2017)
} 
engloba medidas urbanísticas, ambientais e sociais visando melhorias concretas nas áreas em que se pretende a regularização. Projetos de intervenção urbanística, obras de melhoria de infraestrutura e integração com a cidade, chegada de equipamentos e serviços urbanos essenciais, tais são medidas indissociáveis de um processo de regularização fundiária, que não se limita a conceder títulos para os moradores, mas também visa garantir a efetivação de diversos outros direitos sociais.

A conjunção da normativa trazida pela Lei 11.977/2009 com os instrumentos citados anteriormente (em especial a CDRU e a CUEM) revelavam um modelo de regularização fundiária pautado na proteção e valorização das situações possessórias, uma forma de melhor adequar a legislação à realidade dos núcleos urbanos informais (MENDONÇA, 2018, p. 262). Revelava, também, uma busca por afirmar a autonomia da posse em relação à propriedade, procurando alcançar o mesmo nível de proteção jurídica aos dois institutos, de forma a atender uma demanda histórica dos movimentos sociais de luta pela terra (BALDEZ, 1998, p. 90).

Este modelo de regularização, pautado pela proteção e valorização da posse, sofreu uma mudança profunda com o advento da Medida Provisória 759/2016, depois convertida na Lei 13.465/2017. A lei, de caráter nacional (e portanto aplicável aos bens públicos de todos os entes federativos), funda um novo modelo de regularização fundiária, no qual é privilegiada a titulação individual via transferência de propriedade em detrimento das formas de proteção da posse:

A edição da Lei 13.465, de 11 de Julho de 2017, altera a sistemática da regularização fundiária, apresentando um modelo diverso daquele pautado na proteção das situações possessórias. A referida lei revogou parte da Lei 11.977/2009, instituindo uma estrutura de regularização fundiária fundada na transferência da propriedade. Esta mudança de rumos pode ser observada a partir de dois institutos disciplinados nessa lei, a Legitimação de Posse e a Legitimação Fundiária. (MENDONÇA, 2018, p. 262263) 
A Legitimação de Posse $^{11}$ e Legitimação Fundiária ${ }^{12}$ são instrumentos adotados pela nova lei que visam facilitar a transferência da propriedade de imóveis objetos da regularização fundiária urbana (Reurb). Não é de interesse do presente artigo a análise exaustiva de tais dispositivos jurídicos, apenas busca-se nominar os mecanismos pelos quais se busca concretizar o novo modelo instaurado. No entanto, imprescindível mencionar que a nova lei permite a transferência da propriedade de bens públicos inclusive na regularização fundiária de interesse específico (Reurb-E), onde está ausente o interesse social de proteger o direito à moradia de famílias de baixa renda. Tal abertura de portas, cujos efeitos a longo prazo ainda não podem ser previstos por completo, tem o potencial de ocasionar uma grave dilapidação do patrimônio público em benefício de interesses particulares.

Além disso, observa-se que a Lei $13.465 / 17$ prioriza de forma absoluta o aspecto dominial da regularização fundiária, que se destinaria apenas à concessão de títulos de propriedade aos beneficiários da Reurb. Esta concepção mais restrita de regularização fundiária rompe por completo com o conceito pleno que vinha sendo utilizado anteriormente pela Lei 11.977/2009, que previa a adoção das medidas urbanísticas, ambientais e sociais necessárias para assegurar o direito à cidade aos moradores dos núcleos urbanos informais que seriam beneficiados pelo processo de regularização.

Pouco tempo depois de promulgada, a Lei $13.465 / 17$ se tornou objeto de duas ações diretas de inconstitucionalidade, a ADI 5787 e a ADI 5771. Um dos institutos mais questionados pelas ações é própria legitimação fundiária, devido

\footnotetext{
11 Lei 13.465/2017. Art. 25. A legitimação de posse, instrumento de uso exclusivo para fins de regularização fundiária, constitui ato do poder público destinado a conferir título, por meio do qual fica reconhecida a posse de imóvel objeto da Reurb, com a identificação de seus ocupantes, do tempo da ocupação e da natureza da posse, o qual é conversível em direito real de propriedade, na forma desta Lei.

12 Lei 13.465/2017. Art. 23. A legitimação fundiária constitui forma originária de aquisição do direito real de propriedade conferido por ato do poder público, exclusivamente no âmbito da Reurb, àquele que detiver em área pública ou possuir em área privada, como sua, unidade imobiliária com destinação urbana, integrante de núcleo urbano informal consolidado existente em 22 de dezembro de 2016.
} 
ao seu potencial de fomentar processos de grilagem e privatização de terras públicas mesmo por pessoas de alta renda, aprofundando as desigualdades sociais e a concentração de terras. Além disso, o foco exclusivo no aspecto dominial da regularização, sem prever o acompanhamento de demais medidas urbanísticas voltadas para assegurar o direito à cidade nos núcleos informais, contraria a ordem constitucional e frustra os próprios objetivos da regularização fundiária. Segundo o parecer do Ministério Público Federal na ADI 5787, favorável à declaração de inconstitucionalidade da nova lei:

A distribuição de títulos dominiais, decorrentes da privatização de terras públicas e privadas, desacompanhada das medidas necessárias ao exercício do direito de habitação não se coaduna com a ordem constitucional e com o próprio objetivo da regularização fundiária, que deve ter por escopo não a formalização de títulos, mas a garantia da integração dos ocupantes dos imóveis à vida urbana e à vida rural. (2018)

Os objetivos deste novo modelo regulatório são claros: permitir a incorporação de espaços antes excluídos nos circuitos imobiliários formais, estimulando a mercantilização da terra e da moradia ${ }^{13}$. Dentre os riscos de tal movimento estão a intensificação de processos de especulação imobiliária sobre terrenos ocupados por assentamentos informais, especialmente os localizados em áreas valorizadas da cidade, e o agravamento do déficit habitacional que assola o país. Ao tempo da discussão e promulgação da MP 759/16 (depois convertida na Lei 13.465/17), houve forte reação de movimentos sociais de luta pela terra, que emitiram uma carta aberta demonstrando sua contrariedade à nova lei - chamando-a de Lei da Grilagem - e denunciando a desconstrução da regularização fundiária no Brasil:

A MP [759/2016] reforça ainda mais a financeirização dos espaços urbano e rural, fortalecendo ainda mais os negócios bancários e, a longo prazo, a intensificação do mercado imobiliário e fundiário excludente, sobretudo nas metrópoles brasileiras. A

\footnotetext{
13 Observe-se as declarações do Ministro das Cidades, Bruno Araújo ao tempo da promulgação da lei: "o título traz a possibilidade de colocar milhões de ativos na economia, passíveis de serem utilizados no mercado e no acesso ao crédito." (CONGRESSO EM FOCO, 2016) Interessante notar que nenhuma menção à questão da moradia é feita, parece um elemento secundário, irrelevante ao debate da regularização fundiária.
} 
fórmula baseada na mera entrega de títulos conduz ainda ao fortalecimento do conceito privatista da terra e a concepção da propriedade como mero direito, fatores responsáveis pela tradição patrimonialista que constitui e mantém as elites fundiárias no Brasil. (CARTA ABERTA AO BRASIL, 2016)

A ascensão de modalidades regulatórias pautadas pela propriedade privada individual não é uma peculiaridade brasileira, mas sim reflexo de um movimento global do capitalismo financeiro e imobiliário, que afeta diversos países e realidades distintas. Este processo será brevemente abordado a seguir.

\subsection{A Propriedade Privada como Modelo de Regularização: Um Movimento Global}

Raquel Rolnik, urbanista e ex-relatora da ONU sobre direito à moradia, ao analisar as políticas fundiárias adotadas pelos países nas últimas décadas, conclui que "assim como nas políticas habitacionais, a propriedade privada individual ganhou hegemonia sobre todas as outras formas de posse nos programas de reforma e administração fundiária pelo mundo." (2018, p. 153) O estímulo à titulação individual dos assentamentos irregulares como modelo a ser perseguido pelos Estados, impulsionado por atores capitalistas globais como o Banco Mundial e o FMI, é fruto de uma demanda por novos espaços para serem convertidos em capital:

$\mathrm{Na}$ fase financeirizada e rentista do capital, as terras apropriadas sob regimes de posse que não a propriedade individual titulada e registrada, no campo e nas cidades, passam a funcionar como uma reserva, passível de ser ocupada a qualquer momento por frações do capital financeiro em sua fome incessante de novas garantias para seus ativos. Assim, de locus de um exército industrial de reserva, as favelas do mundo convertem-se em novas reservas de terra para a extração de renda, sob a hegemonia do complexo imobiliário-financeiro. (ROLNIK, 2018, p. 166/167)

A irregularidade fundiária e a ausência de um registro formal de propriedade, marca sintomática das cidades brasileiras, se apresenta como um grande obstáculo que limita a penetração do circuito imobiliário e financeiro nos 
assentamentos informais. Tratam-se de imensas camadas de território impassíveis de serem convertidos em mercadoria pelos mecanismos formais ${ }^{14}$, um verdadeiro "capital morto" ${ }^{15}$ na concepção dos que apenas enxergam na terra a possibilidade de se extrair renda. Desta forma, programas de regularização fundiária pautados pela titulação da propriedade tornam-se um dos pilares para a expansão deste complexo imobiliário-financeiros, principalmente nos países emergentes, permitindo que espaços antes inacessíveis sejam apropriados e transformados em ativos mercantis ou financeiros.

No contexto da América Latina, um dos maiores ideólogos da política de titulação da propriedade privada para assentamentos informais é o economista e ex-assessor do governo peruano Hernando de Soto, especialmente a partir da publicação de seu livro "O Mistério do Capital", em 2001. Ele foi responsável por uma política massiva de titulação de favelas no Peru, e também trabalhou ativamente para disseminar o modelo para outras realidades. O impacto global de suas ideias foi imenso, influenciando políticas fundiárias em países com contextos bastante distintos, e muitos autores enxergam a presença de seu pensamento na formulação do novo marco jurídico da regularização fundiária no Brasil, a Lei 13.465/2017 (FERREIRA, 2018).

A hipótese de De Soto é que, a partir do momento que os pobres consigam acessar os circuitos capitalistas formais, eles conseguirão por meio de seu esforço individual ascender socialmente e sair da condição da pobreza. $\mathrm{O}$ primeiro passo para isto, segundo ele, é regular seus direitos de propriedade, de forma a permitir que sua moradia se torne um ativo passível de gerar capital:

\footnotetext{
14 No entanto, não ignoramos a existência de um vasto e desenvolvido mercado informal de posses dentro dos espaços irregulares, seja na forma do aluguel da posse ou da própria cessão onerosa. Muitas vezes estes intercâmbios são mediados pelas próprias associações de moradores locais, já que o Estado não reconhece oficialmente a legalidade de tais operações. Seria um erro, portanto, concluir que a irregularidade fundiária impede a mercantilização da terra.

15 Referência à expressão utilizada por Hernando de Soto, grande ideólogo do modelo de titulação de comunidades informais, ao se referir às propriedades não registradas em favelas. (GOIS, 2001)
} 
As casas dos pobres estão construídas sobre lotes com direitos de propriedade inadequadamente definidos, as empresas não estão constituídas com obrigações claras e as indústrias se ocultam onde os financistas e investidores não podem vê-las. Sem direitos adequadamente documentados, essas posses resultam em ativos difíceis de converter em capital, não podem ser comercializadas fora dos estreitos círculos locais onde as pessoas mantêm confiança mútua, não servem de garantia para um empréstimo nem como participação em um investimento. (DE SOTO, 2001, p. 32)

A defesa da titulação da propriedade como mecanismo de superação da pobreza se fundamenta basicamente na premissa de que "uma vez que os pobres tenham a terra titulada, o mercado fará o resto" (ROLNIK, 2018, p. 212), retirando o dever do Estado de assegurar os direitos sociais básicos. Temas como a redução das desigualdades e distribuição da riqueza são afastados do debate, que apenas é pautado pela iniciativa individual de ascender socialmente através da propriedade. A utopia do capitalismo para todos vem sendo adotada como política pública por diversos países, e programas de titulação individual de favelas são cada vez mais comuns no mundo.

Nas últimas décadas, uma série de estudos vem contestando a efetividade desta política de regularização fundiária como solução para a pobreza e melhoria das condições de vida em favelas. Evidências produzidas indicam que muitas das premissas do modelo não ocorrem na realidade, dentre elas apresentamos algumas: (i) a titulação não tem um impacto direto no acesso ao crédito formal por parte dos moradores (por conta de outras espécies de limitações burocráticas ou simplesmente da preferência por arranjos informais já existentes nas comunidades); (ii) a titulação não aumenta a segurança da posse (já que sua efetivação está mais relacionada com a percepção - cultural, política, social - da possibilidade de permanência do que com a existência de um título formal registrado) e, principalmente; (iii) programas de titulação não foram capazes de melhorar a qualidade de vida nos assentamentos (porque não garante por si só a efetivação dos direitos sociais, sendo imprescindível a tutela estatal através da política pública) (ROLNIK, 2018, p. 213-216). 
Além disso, programas que priorizam de forma absoluta a titulação da propriedade correm o risco de menosprezar e invisibilizar as demais situações possessórias, que hoje comportam boa parte do território urbano no Brasil, o que pode prejudicar ainda mais a segurança da posse dos moradores inseridos em regimes não-proprietários. Esta preocupação é salientada pela Relatoria Especial sobre moradia adequada em informe para o Conselho de Direitos Humanos da ONU:

A diferencia del discurso dominante en materia de tenencia, los títulos de plena propiedad no son el único instrumento de una tenencia segura. A menudo las políticas que promueven la propiedad individual reducen a la vez el apoyo a otras formas de tenencia. Esas políticas conllevan el riesgo de excluir y menoscabar la situación de tenencia de amplios sectores de la población urbana y periurbana, en particular de la población más pobre, lo que da lugar a un retroceso en el ejercicio del derecho a una vivienda adecuada. Por el contrario, las políticas que favorecen diversas formas de tenencia pueden mejorar la seguridad del acceso a la vivienda para diversos grupos de población16. (ASSEMBLEIA GERAL DA ONU, 2013)

Apesar de se apresentarem como novo marco de regularização fundiária, no Brasil e no mundo, modelos de titulação individual não têm dado conta da complexidade das dinâmicas de comunidades informais. Afortunadamente, não estamos diante de uma situação binária, na qual apenas podemos optar pela irregularidade ou pela propriedade individual, existem diversas outras modalidades de relação com o território que merecem atenção. Dentre elas, uma forma de gestão coletiva da propriedade que é objeto do presente estudo: o Termo Territorial Coletivo.

\footnotetext{
${ }^{16}$ Diferentemente do discurso dominante em matéria de posse, os títulos de plena propriedade não são o único instrumento para uma posse segura. Frequentemente as políticas que promovem a propriedade individual reduzem por sua vez o apoio a outras formas de posse. Essas políticas assumem o risco de excluir e menosprezar a situação de posse de amplos setores da população urbana e periurbana, em particular a população mais pobre, o que dá lugar a um retrocesso no exercício do direito a uma moradia adequada. Pelo contrário, as políticas que favorecem diversas formas de posse podem melhorar a segurança do acesso à moradia para diversos grupos da população. (Tradução livre)
} 


\section{CAPÍTULO 2 - O TERMO TERRITORIAL COLETIVO}

Antes de adentrarmos na conceituação e genealogia do Termo Territorial Coletivo, cabe tomar uma nota inicial a respeito da nomenclatura utilizada. Por ser uma figura inexistente no direito brasileiro, não foi feita uma tradução oficial do instrumento, que é originalmente chamado de Community Land Trust (CLT) nos Estados Unidos e demais países da língua inglesa. A dificuldade da tradução se evidencia pela presença da figura do land trust, que não conta com figura equivalente no direito brasileiro. Em espanhol, ele é comumente referido como Fideicomisso Colectivo de Tierras ${ }^{17}$.

Para os fins do presente trabalho, foi feita a escolha pela nomenclatura Termo Territorial Coletivo, por ser a que melhor captura a essência do instrumento (FIDALGO, 2018, p. 1): seu caráter consensual e de livre manifestação da vontade - um acordo, um termo; o objeto sob o qual se pretende operar - o território e, por fim; seu aspecto comunitário e forma de organização - fundamentalmente coletiva.

São diversas as definições dos TTCs apresentadas, e suas características essenciais serão abordadas mais à frente, mas podemos dizer em termos gerais que se trata de um modelo de gestão coletiva do território no qual a terra pertence à coletividade que nele reside - através da figura de uma organização sem fins lucrativos que detém sua titularidade, e é regida pelos moradores - enquanto as casas e construções são de propriedade individual de seus usuários. O seu objetivo final é retirar o território do mercado imobiliário, garantindo moradia acessível de forma contínua e a permanência das comunidades em seus espaços.

\footnotetext{
${ }^{17}$ Nomenclatura utilizada em resolução da ONU sobre moradia adequada como componente do direito à vida, que discorre sobre segurança da posse e discute diversas modalidades de proteção da posse e relação com o território. (ASSEMBLEIA GERAL DA ONU, 2013a, pár. 20).
} 


\subsection{Origem e Evolução}

O Termo Territorial Coletivo surge nos Estados Unidos na década de 1960, no contexto dos movimentos por direitos civis, e de início foi pensado como um mecanismo de aquisição de terras agrícolas para a subsistência e desenvolvimento econômico de comunidades negras marginalizadas pela política de segregação (DAVIS, 2010, p. 16). O primeiro TTC da história foi fundado na zona rural do estado de Geórgia, por Robert Swann (ativista social) e Slater King (militante por direitos civis, advogado e primo de Martin Luther King Jr.), e foi chamado de New Communities Inc. Após a aquisição de cerca de 12.000 hectares de terra cultivável, foram feitos contratos de concessão (lease) com fazendeiros negros, que de outra forma não seriam capazes de adquirir a terra individualmente. A ideia era formar uma organização sem fins lucrativos que obtivesse a titularidade da terra e garantisse a permanência das comunidades rurais no local, a partir de concessões de uso por tempo indeterminado e com preços acessíveis.

Segundo John Emmeus Davis (2010), os pioneiros na implementação deste modelo foram profundamente influenciados pelas ideias de Henry George (1839-1897), importante pensador norte americano que enxergava a pobreza como resultado de um regime social no qual uma pequena casta de proprietários se apropria da riqueza derivada da crescente valorização da terra, consequência do desenvolvimento progressivo da sociedade. George, por sua vez, se baseava nos princípios filosóficos de John Stuart Mill, que escreve:

The ordinary progress of a society which increases in wealth, is at all times tending to augment the incomes of landlords: to give them both a greater amount and a greater proportion of the wealth of the community, independently of any trouble or outlay incurred by themselves. They grow richer, as it were in their sleep, without working, 
risking, or economizing. What claim have they, on the general principle of social justice, to this accession of riches? (MILL, 1848, cit in DAVIS, 2010, p. 39) 18

Segundo Mill, os senhores de terra se apropriam indevidamente da valorização que a terra sofre, fruto do desenvolvimento natural da sociedade como um todo, sem que tenham feito nada para merecer este enriquecimento. Esta apropriação da riqueza, derivada do monopólio do domínio sobre a terra, tende a se manter constante com o passar do tempo, perpetuando uma estrutura de desigualdade permanente. Inspirado nas ideias de Mill, Henry George considerava o monopólio da propriedade da terra nas mãos de poucos a causa principal da desigualdade e da pobreza. Para atacar este problema, ele defendia que a terra deveria pertencer à coletividade que nela reside, e não ser apropriada de forma individual por uma pequena classe de proprietários. Este princípio seria adotado posteriormente pelos criadores do modelo TTC:

To extirpate poverty, to make wages what justice commands they should be, the full earnings of the laborer, we must therefore substitute for the individual ownership of land a common ownership [...] the unequal ownership of land necessitates the unequal distribution of wealth. (GEORGE, 1879/1912, cit in ENGELSMAN et al, 2016, p. 594) 19

Na gênese da formulação do Termo Territorial Coletivo, reside a ideia de que a terra não se trata de um mero ativo para o enriquecimento individual de seu proprietário, e qualquer valorização que ela venha a sofrer com o passar do tempo deve beneficiar a comunidade como um todo. A terra é, portanto, entendida como uma herança comum, devendo responder apenas às demandas

\footnotetext{
$18 \mathrm{O}$ progresso habitual de uma sociedade que cresce em riqueza, tende a todo tempo a aumentar os rendimentos dos senhores de terra: dar a eles tanto uma maior quantidade quanto uma maior proporção da riqueza da comunidade, independentemente de qualquer esforço ou despeza empregada por eles. Eles se tornam mais ricos, como se estivessem dormindo, sem trabalhar, arriscar ou economizar. Qual reivindicação eles possuem, com base no princípio geral de justiça social, para este acréscimo de riqueza? (Tradução livre)

${ }^{19}$ Para erradicar a pobreza, para fazer os salários o que a justiça determina que eles devem ser, o pleno rendimento do trabalhador, nós devemos portanto substituir pelo domínio individual da terra um domínio coletivo [...] o domínio desigual da terra obriga a distribuição desigual da riqueza. (Tradução livre)
} 
da coletividade que ela abriga, e sempre atender à finalidade social que ela se propõe.

Apesar de surgir no contexto rural, é nas cidades que o instrumento ganha visibilidade e se desenvolve com rapidez, se relacionando com novas formas de vulnerabilidade e adotando novas estruturas organizacionais. Fenômenos como a valorização imobiliária, a gentrificação dos espaços e o aumento dos custos com a moradia são apontados como problemas que justificariam a implementação do instrumento no contexto urbano. Os primeiros TTCs urbanos surgem nos anos 1980 em cidades norte americanas, implementados para servir como um mecanismo promoção de moradia acessível para comunidades pobres urbanas de forma permanente (DAVIS, 2010, p. 22). Através da retirada da terra do mercado imobiliário, e de mecanismos internos de controle sobre o preço das vendas das casas sob o modelo, o instrumento permite o acesso e permanência de populações carentes inclusive em áreas valorizadas da cidade.

A partir dos bons resultados alcançados pelas experiências dos Termos Territoriais Coletivos urbanos, a ferramenta se proliferou de forma acelerada por todo o território americano. Rapidamente, o que era modelo se torna movimento, a nível nacional, de defesa do TTC como uma forma assegurar o controle do território pela comunidade (DAVIS, 2010, p. 26). Diversos TTCs espalhados pelo país se unem e formam redes de apoio e de disseminação de conhecimento e experiências. Em 1982, é lançado o primeiro Community Land Trust Handbook, documento que seria produzido e divulgado de forma cíclica, compilando experiências de sucesso de TTCs, boas práticas que devem reger o modelo, problemas e dificuldades enfrentadas e novos rumos (DAVIS, 2010, p. 23).

Hoje, os Estados Unidos contam com mais de 250 TTCs em funcionamento (ASSEMBLEIA GERAL DA ONU, 2013b, par. 58), regulamentações próprias em diversos estados, isenções fiscais devido ao seu caráter social e amplo apoio do Poder Público (DAVIS, 2010, p. 34). Em 2017, 
o instrumento foi reconhecido pela Nova Agenda Urbana - documento da ONU, adotado na Conferência de Quito sobre Moradia e Desenvolvimento Urbano Sustentável (Habitat III) e que estabelece diretrizes globais de políticas urbanas e habitacionais - como uma opção de moradia sustentável e acessível, devendo ser apoiada pelos Estados (pár. 107). Esta crescente visibilidade do potencial do Termo Territorial Coletivo na promoção de moradia acessível de forma permanente vem estimulando sua disseminação pelo mundo.

Nas últimas décadas, o modelo vem sendo estudado e implementado em diversos países, como o Reino Unido $^{20}$, Bélgica ${ }^{21}$, França ${ }^{22}$, Austrália ${ }^{23}$, Quênia $^{24}$, Porto Rico, entre outros (UN-HABITAT, 2012). Podemos observar um crescimento vertiginoso instrumento principalmente nesta última década, marcada pela falência do modelo financeiro de produção habitacional que culminou na crise imobiliária de 2008. É bastante possível que este cenário de crise tenha contribuído para a abertura de portas para a discussão de novas soluções urbanas para a satisfação do direito à moradia, em um contexto de crescente despossessão dos mais pobres.

\footnotetext{
${ }^{20}$ Na Inglaterra e País de Gales, o número de TTCs saltou de 14 para mais de 300 na última década. Assim como nos EUA, o modelo foi implementado primeiramente no campo como forma de garantir acesso à terra para comunidades rurais com poucos recursos e, posteriormente, foi transportado para as cidades como forma de combater a crise imobiliária e habitacional que se aprofundava no país (NELSON, 2019).

${ }^{21} \mathrm{Na}$ Bélgica, o instrumento foi adotado pela primeira vez na capital do país, a cidade de Bruxelas, em um contexto de aumento dos custos da moradia e deslocamento da população para as zonas periféricas. Ele é utilizado como mecanismo que garante a permanência de populações de baixa renda nas áreas centrais da cidade. (VADOT, 2019)

${ }^{22} \mathrm{Na}$ França, o movimento de implementação do TTC começa a partir da formação de uma rede nacional que busca disseminar os valores do modelo, e ao mesmo tempo pressionar o Poder Legislativo para formularem um marco legal que viabilize a existência do instrumento. (MAJCEN, 2019)

${ }^{23} \mathrm{Na}$ Austrália, o TTC vem sendo estudado como uma possível forma de regulação dos territórios pertencentes às comunidades aborígenes e a outros grupos indígenas (CRABTREE, 2015).

24 No Quênia, foi feito um projeto de implementação de um TTC como forma de promover o desenvolvimento de um assentamento precário nos arredores da cidade de Voi, no final dos anos 1990. Trata-se de uma outra ocasião na qual o instrumento foi utilizado no contexto de uma comunidade informal. Apesar da enorme relevância de informações sobre a experiência do local, infelizmente poucos dados são disponibilizados (BASSET, 2007).
} 
A proliferação do TTC pelo mundo é acompanhada por um contínuo aperfeiçoamento do modelo para realidades distintas, o que é possível devido ao seu caráter altamente flexível e adaptável. Uma das premissas do modelo é a possibilidade de construir formatos estatutários dos mais diversos, permitindo que ele seja reformulado de acordo com as peculiaridades de diferentes contextos. Nas palavras de Davis:

The CLT has been reinvented repeatedly over the years, adapting to new audiences, conditions and applications. Such flexibility has been a perennial source of renewal and vigor, helping the CLT to spread far and wide. A deeper appreciation for the model's evolution may encourage today's practitioners to continue the experimentation that gave rise to the model in the first place. ${ }^{25}$ (p. x)

Desta forma, o modelo permite um grau elevado de experimentação e moldagem, de forma a atender necessidades pontuais e específicas de situações distintas. Apesar deste alto grau de flexibilidade, existem elementos comuns e essenciais de qualquer Termo Territorial Coletivo, que serão analisados a seguir.

\subsection{Características Essenciais}

É possível dizer que existem pelo menos cinco características fundamentais encontradas em qualquer Termo Territorial Coletivo (FIDALGO, 2018, p. 2): (i) adesão espontânea de seus membros; (ii) terra de propriedade coletiva; (iii) casas e construções de propriedade individual; (iv) gestão coletiva do território e; (v) acessibilidade econômica da moradia por populações carentes de forma permanente. Prosseguiremos na análise de cada uma delas.

Por adesão espontânea, entende-se que deve haver liberdade na escolha de constituir ou aderir a um Termo Territorial Coletivo. Ninguém pode ser

\footnotetext{
${ }^{25}$ O TTC foi reinventado repetidamente ao longo dos anos, se adaptando a novas audiências, condições e aplicações. Essa flexibilidade tem sido uma força perene de renovação e vigor, auxiliando o TTC a se espalhar pelo mundo. Uma apreciação mais profunda da evolução do modelo pode encorajar os praticantes de hoje a continuar o processo de experimentação que deu origem ao modelo em primeiro lugar. (Tradução livre)
} 
obrigado a participar de um TTC, a livre manifestação da vontade dos moradores é essencial para a implementação do instrumento.

A propriedade coletiva da terra é um elemento importante do modelo, e merece atenção especial. Por propriedade coletiva, não se pretende afirmar que a terra está registrada sob o nome de todos que nela habitam, ou que há mais de um titular de sua propriedade. Em todo Termo Territorial Coletivo, forma-se uma organização sem fins lucrativos para se tornar a proprietária do terreno, organização esta que é regida coletivamente pelos moradores e atua representando seus interesses. Desta forma, a terra pertence à todos os seus residentes, através de sua condição de membro permanente do TTC. O objetivo deste arranjo é impedir que pessoas negociem individualmente a propriedade imobiliária, afastando a interferência de interesses especulativos e mantendo o valor da terra estável e permanentemente acessível por famílias de baixa renda.

A propriedade individual das casas e construções garante uma autonomia dos moradores em usar e dispor de seus bens como desejarem. É permitida a troca, venda, aluguel e outras formas de utilização dos imóveis podendo o TTC estabelecer regras e limitações com fins de preservar seu objetivo de promover moradia acessível - e todas as benfeitorias efetuadas que gerem valorização no bem pertencem aos seus usuários. São diversos os arranjos jurídicos que permitem uma separação entre a propriedade da terra e a propriedade das construções, alguns TTCs se utilizam da figura do direito de superfície, e em outros há contratos de arrendamento de terreno por largos períodos de tempo, tipicamente 99 anos (ASSEMBLEIA GERAL DA ONU, 2013b, pár. 57).

A gestão coletiva da propriedade é talvez a característica mais importante do instrumento. A pessoa jurídica formada para obter a titularidade da terra é composta pelos próprios moradores que nela habitam, e são eles que elegem os membros do conselho diretor responsável por gerir a propriedade. Este conselho pode constituir-se de diversas formas, mas tradicionalmente se adota uma 
estrutura tripartite (DAVIS, 2010), na qual $1 \frac{1}{3}$ de seus membros é composto por moradores membros do TTC, $1 / 3$ por vizinhos e residentes das comunidades do entorno, e $1 / 3$ de assessores técnicos externos, podendo estar incluídos aqui representantes do Poder Público. No entanto, a natureza flexível do instrumento permite a adoção de arranjos institucionais diversos, como é o caso do TTC Caño Martín Peña em Porto Rico, em que seus membros escolheram um formato no qual é obrigatória a maioria de moradores no conselho diretor (ALGOED, 2018, p. 20).

O conselho é responsável por gerir a propriedade e a pessoa jurídica do TTC, determinando como a terra deverá ser utilizada e impondo normas de uso comum para seus membros. Apesar da finalidade central ser a produção de moradia, muitos TTCs exercem atividades econômicas diversas, que visam garantir sua sustentabilidade financeira - como a locação de espaços não utilizados para fins comerciais, por exemplo - sempre com os lucros revertidos em melhorias para a comunidade. Desta forma, a organização comunitária, em sua condição de proprietária da terra, poderá perseguir de forma autônoma o desenvolvimento local.

Por fim, a acessibilidade econômica da moradia de forma permanente compreende o objetivo central do Termo Territorial Coletivo. Por deter a propriedade da terra e retirá-la do mercado imobiliário, apenas as construções podem ser objeto de trocas comerciais, o que por si só já reduz drasticamente o valor das transações imobiliárias (GUIMARÃES, 2005). Além disso, existem diversos mecanismos pelos quais o TTC visa garantir os baixos custos dos imóveis (UN HABITAT, 2012, p. 22), como a imposição de um teto para a venda e aluguel das casas, limitações acerca dos possíveis compradores (evitando, por exemplo, que empresas ou conglomerados imobiliários adquiram imóveis, de forma a privilegiar o acesso de famílias de baixa renda), direito de preferência (no qual, se um dos moradores quiser vender sua casa, o próprio 
TTC pode exercer a preferência e adquiri-la, para depois revendê-la por um custo acessível), entre outros.

Neste ponto, é importante fazer um parêntese. Ao aderir a um TTC, indivíduos abrem mão de se beneficiarem de qualquer valorização que a terra venha a sofrer, de forma a manter o valor das casas permanentemente acessível (ENGELSMAN et all, 2016, p. 598). A autonomia individual de disposição da casa é profundamente limitada para assegurar o alcance de seu objetivo fundamental: manter a moradia a preços acessíveis de forma permanente, permitindo que famílias de baixa renda possam acessá-las e que a habitação não esteja sujeita às flutuações de mercado.

A reunião destas características configura o modelo do Termo Territorial Coletivo, no qual a terra deixa de ser um mero ativo mercantil para atrelar-se à função social de garantir moradia. Impassível de ser comercializada, é afastado o interesse mercadológico na terra - que mantêm seu valor estável e acessível e ao mesmo tempo é estimulada a participação comunitária no desenvolvimento local. Além disso, algumas pesquisas apontam o potencial do modelo para frear a processos de despossessão causada por execuções hipotecárias, fenômeno extremamente comum nos Estados Unidos à época da crise imobiliária de 2008 (THADEN, ROSENBERG, 2010, p. 4).

Tradicionalmente, no entanto, o Termo Territorial Coletivo apenas é capaz de atender às necessidades de pessoas com rendimentos baixos ou moderados ${ }^{26}$, mas não consegue alcançar a camada dos $15 \%$ mais pobres da população, exceto em raras ocasiões (ASSEMBLEIA GERAL DA ONU, 2013b, par. 61). A primeira vez que um Termo Territorial Coletivo foi implementado em um assentamento urbano precarizado foi em Porto Rico, experiência que será abordada em seguida.

\footnotetext{
${ }^{26}$ Uma pesquisa realizada em 2010 nos Estados Unidos conclui que os moradores de TTCs em áreas urbanas possuem um salário equivalente a $65 \%$ do rendimento médio da comunidade local (UNHABITAT, 2012, p. 24).
} 


\subsection{Importação do Modelo para a Favela: o TTC Caño Martín Peña}

O Fideicomiso de la Tierra ${ }^{27}$ Caño Martín Peña foi instituído em 2004 em um território que abriga cerca de 2.000 famílias de 8 comunidades localizadas nos entornos do canal Martín Peña, que atravessa o centro da cidade de San Juan, capital de Porto Rico. São comunidades que se formaram em meados do século $\mathrm{XX}$, a partir do massivo êxodo rural que o país sofreu, e que resultou em um crescimento desenfreado das cidades (ALGOED, 2018, p. 7-10). A situação das comunidades era trágica, contava com uma estrutura urbana extremamente precária, marcada por irregularidades e insegurança da posse (já que o terreno era, em sua maioria, público) e sofria com as constantes inundações do canal, que se encontrava contaminado com lixo e esgoto.

No início dos anos 2000, uma proposta de ação do governo de dragar o canal e promover a recuperação ambiental do local acabou se transformando em um projeto de desenvolvimento integral para a comunidade, denominado de Projeto ENLACE. Com forte participação comunitária, foram discutidos diversos temas de preocupação dos moradores, como o risco de remoção, a carência de serviços públicos, e os modelos de regularização fundiária que melhor atenderiam suas necessidades:

Los participantes, trabajando en grupos, enumeraron los problemas buscaban resolver al regularizar la tenencia de la tierra, tales como formalizar los servicios básicos, tener acceso a préstamos o dejar una propiedad en herencia. Discutieron la importancia de evitar el desplazamiento de la comunidad. Analizaron, con ayuda de personas conocedoras, las distintas modalidades de tenencia de la tierra, tales como la propiedad individual, la propiedad cooperativa, y la propiedad colectiva a través de los fideicomisos comunitarios de terrenos (community land trust) y concluyeron que los modelos de tenencia colectiva de la tierra, además de atenderlas, les permitían prevenir el desplazamiento de la comunidad28. (ALGOED, 2018, p. 15)

\footnotetext{
${ }^{27}$ Nome utilizado em espanhol para o Community Land Trust, ou Termo Territorial Coletivo.

28 Os participantes, trabalhando em grupos, enumeraram os problemas que buscavam resolver ao regularizar a posse da terra, tais como formalizar os serviços básicos, ter acesso à empréstimos ou deixar
} 
No desenrolar das atividades do projeto, os moradores concluíram que modelos de propriedade coletiva seriam mais efetivos na proteção dos interesses da comunidade. Havia uma preocupação imensa com a remoção não só decorrente das intervenções do poder público, mas também das pressões do mercado imobiliário com a eventual valorização da terra (eis que o assentamento está localizado em área central da cidade), que seria impulsionada através da titulação individual dos moradores. Foi escolhido, ao final das oficinas, o Termo Territorial Coletivo como modelo a ser implementado no local.

Para a implementação do instrumento, foi constituído um grupo de representantes das 8 comunidades envolvidas no projeto, denominado de G-8. Posteriormente, foi promulgada a lei 489/2004, que institui oficialmente o Fideicomiso de la Tierra Caño Martín Peña e reconhece o G-8 como entidade representativa da comunidade. Segundo a lei, o TTC deterá a propriedade do solo e ficará impossibilitado de dispor do terreno, apenas é permitida a venda das edificações ou outorga de arrendamentos a longo $\operatorname{prazo}^{29}$. A figura jurídica adotada para concretizar TTC foi a do Fideicomisso ${ }^{30}$, na qual o fideicomitente é quem transfere a propriedade (no caso, o governo, já que a terra era pública), o fiduciário é quem recebe a propriedade da terra e a administra em benefício da comunidade (o conselho gestor da organização sem fins lucrativos criada para deter a titularidade da terra, chamado aqui de Junta de Fiduciários) e o

uma propriedade de herança. Discutiram a importância de evitar o desalojamento da comunidade. Analisaram, com ajuda de pessoas conhecedoras, as distintas modalidades de posse de terra, tais como a propriedade individual, a propriedade cooperativa e a propriedade coletiva através dos termos territoriais coletivos (community land trusts) e concluíram que os modelos de posse coletiva da terra, além de atendê-las, lhes permitiam prevenir o desalojamento da comunidade. (Tradução livre)

${ }^{29}$ Art. 19 Ley 489/04: El Fideicomiso de la Tierra retendrá la titularidad del suelo, y sólo se podrá vender o transferir el derecho sobre la edificación; o se podrán otorgar arrendamientos a largo plazo con derecho a heredarse. Los propietarios en terrenos del Fideicomiso podrán ser dueños exclusivamente de la estructura pero no de la tierra donde enclava. Los residentes de los terrenos que sean propiedad del Fideicomiso serán los fideicomitentes

${ }^{30}$ Trata-se de uma figura existente no ordenamento jurídico brasileiro, mas restrito ao âmbito do direito sucessório (Código Civil, art. 1.951-1.960). 
fideicomissário são os beneficiários finais da administração do bem (os próprios moradores da comunidade).

O conselho gestor do TTC Caño Martín Peña é formado por 11 pessoas, sendo seis moradores da comunidade - com o objetivo de assegurar o controle comunitário sobre a organização - dois consultores externos e três representantes de instituições governamentais (ALGOED, 2018, p. 20). A forma de nomeação dos representantes membros do conselho é mista. Dos seis moradores que compõe o conselho, dois deles são designados pelo G-8 (grupo de representantes das 8 comunidades do TTC), e quatro são eleitos em assembleia por todos os moradores. Os três representantes do Poder Público são nomeados pelo próprio governo, um deles pelo governo central, outro pelo governo municipal e o terceiro por uma Junta de Diretores. Os restantes dois consultores externos (cidadãos particulares que residem da cidade de San Juan) são designados pela própria Junta dos Fiduciários, em acordo comum. Os mandatos dos membros do conselho variam entre 4, 5 ou 6 anos, e fica vedada a permanência no cargo de membro do conselho por mais de dois mandatos consecutivos.

$\mathrm{O}$ instrumento adotado para garantir a propriedade individual das casas e construções foi o direito de superfície, direito real que permite a dissociação entre propriedade do solo e a propriedade das construções, sendo a primeira de titularidade do TTC e a segunda dos próprios moradores. Este título deverá contar com escritura pública e ser inscrito no Registro Geral de Propriedade Imobiliária do local, e ele é responsável por oficializar a relação com a terra das famílias membros do TTC. Pela primeira vez, os moradores obtiveram um documento oficial que reconhece seu direito como donos de suas casas.

Após a implementação do TTC Caño Martín Peña, cerca de 2000 famílias residentes de comunidades informais se tornaram coletivamente proprietárias de um dos maiores terrenos da cidade de San Juan. Além da regularização da situação possessória dos moradores da área, o TTC pôs em prática diversos projetos de desenvolvimento local e recuperação ambiental, e fortaleceu a 
organização comunitária na gestão do território, facilitando inclusive a comunicação e o poder de barganha com o governo local. Em 2015, ele recebeu um prêmio da World Habitat Awards, organização ligada à ONU que analisa iniciativas habitacionais, como modelo de moradia sustentável.

O sucesso da experiência de Porto Rico demonstra que o Termo Territorial Coletivo pode ser um instrumento eficaz de desenvolvimento, promoção de moradia e garantia da segurança da posse em assentamentos informais e precarizados. A aplicação do modelo na realidade brasileira é complexa, e esbarra nas profundas diferenças entre os mecanismos jurídicos existentes. No entanto, as similaridades entre os contextos das favelas do Caño Martín Peña em Porto Rico e das favelas do Brasil são enormes, o que nos dá indícios do potencial que o TTC tem de garantir a segurança da posse e promoção da moradia também na realidade fundiária urbana nacional. 


\section{CAPÍTULO 3 - A APLICABILIDADE DO TTC NO CONTEXTO URBANO BRASILEIRO}

$\mathrm{Na}$ primeira parte deste trabalho, buscou-se demonstrar como a propriedade privada individual se tornou hegemônica diante de outras formas de relação com o território, ocupando papel central nas políticas de regularização fundiária de assentamentos urbanos informais no Brasil e no mundo. Foram traçados alguns dos efeitos deste processo para a efetivação do direito à moradia adequada, principalmente no que tange à segurança da posse. Em seguida, foi exposta uma outra modalidade de relação com o território, que enfatiza o caráter coletivo da propriedade da terra e impossibilita sua transformação em mercadoria, buscando prover moradia acessível de forma permanente. Cabe compreender agora se este modelo é passível de ser aplicado no Brasil, a partir da legislação vigente e do momento atual da regularização fundiária no país.

Antes de adentrar na análise da possibilidade jurídica de aplicação do instrumento, é preciso tomar uma nota inicial. O Termo Territorial Coletivo não busca romper com a lógica da propriedade privada. Pelo contrário, ele depende da propriedade para existir, já que toda a terra gerida através do modelo é de titularidade da organização comunitária constituída. Seu objetivo é simplesmente minimizar os efeitos negativos da mercantilização do território para a moradia, a partir de uma fórmula de gestão coletiva da propriedade na qual a terra é retirada do mercado imobiliário e fica atrelada à sua finalidade social de garantir habitação.

\subsection{Considerações Jurídicas}

Conforme foi exposto anteriormente, o TTC tem suas origens nos Estados Unidos, país que adota o sistema da common law, e daí surge a primeira 
dificuldade de importação para o sistema jurídico brasileiro (civil law). Sendo caracterizado por um rigor formalista e legalista excessivo, o marco normativo nacional acaba dificultando o sucesso de arranjos jurídicos criativos que buscam possibilitar a existência de institutos não positivados em lei, como é o caso do Termo Territorial Coletivo. No entanto, há diversos mecanismos jurídicos que podem viabilizar a implementação do instrumento a partir da legislação vigente, em especial diante do momento atual da política de regularização fundiária nacional. Vejamos alguns deles.

Como vimos, a característica principal do Termo Territorial Coletivo é a separação entre a propriedade da terra (coletiva) e a propriedade das casas e construções (individual). Uma das figuras jurídicas que possibilitam este formato é o direito de superfície, regulado pelos arts. 1.369 a 1.377 do Código Civil e pelos arts. 21-24 do Estatuto da Cidade (Lei 10.257/2001), onde ele é elencado como instrumento da política urbana. O direito de superfície é definido por Orlando Gomes como "o direito real de ter uma construção ou plantação em solo alheio" (GOMES, 2002). Ele é concedido pelo proprietário do terreno (superficiente) ao detentor do direito (superficiário), por tempo determinado ou indeterminado $^{31}$, de forma onerosa ou gratuita ${ }^{32}$ e devendo ser registrado no Cartório de Registro de Imóveis. Trata-se de um direito transferível a terceiros ${ }^{33}$ - portanto passível de ser negociado - e transmissível aos herdeiros no caso de morte do superficiário ${ }^{34}$.

\footnotetext{
${ }^{31}$ Estatuto da Cidade (Lei 10.257/2001). Art. 21. O proprietário urbano poderá conceder a outrem o direito de superfície do seu terreno, por tempo determinado ou indeterminado, mediante escritura pública registrada no cartório de registro de imóveis.

32 Estatuto da Cidade (Lei 10.257/2001). Art. 21. § 2o A concessão do direito de superfície poderá ser gratuita ou onerosa.

33 Estatuto da Cidade (Lei 10.257/2001). Art. 21. § 4º O direito de superfície pode ser transferido a terceiros, obedecidos os termos do contrato respectivo.

34 Estatuto da Cidade (Lei 10.257/2001). Art. 21. § 5ํㅜ Por morte do superficiário, os seus direitos transmitem-se a seus herdeiros.
} 
Segundo as lições de Nelson Rosenvald, o direito de superfície possui natureza dupla. Por um lado, é direito real atrelado a coisa alheia, e por outro é verdadeira propriedade:

Em virtude da omissão do Estatuto da Cidade e do Código Civil quanto à natureza jurídica do modelo, repercute-se na doutrina uma polêmica. Seria o direito real de superfície uma verdadeira propriedade ou um direito real em coisa alheia? A resposta é: ambos. O direito de superfície é um direito real sobre coisa alheia (lote ou gleba), pois sua formação resulta de uma concessão do titular da propriedade para fins de futura edificação (sobre ou sob o solo) ou plantação, que, quando concretizada pelo superficiário (concessionário), converterá o direito inicialmente incorpóreo, em um bem materialmente autônomo à propriedade do solo do concedente. (ROSENVALD, 2009, p. 432)

Desta forma, o direito de superfície garante a propriedade da construção ao superficiário, que possui autonomia para usar e dispor dela como desejar, mas impede a negociação da terra, que pertence à pessoa jurídica do TTC. Dentro do modelo do Termo Territorial Coletivo, o superficiente - ou proprietário do terreno - seria a organização comunitária constituída, enquanto o superficiário ou proprietários das casas - seriam os moradores da comunidade. Mantém-se, portanto, o caráter coletivo da terra, e individual das construções, marca característica do TTC.

Além da necessidade de se separar a propriedade do solo da propriedade das casas, o que é alcançado através da figura do direito de superfície, um dos principais desafios da implementação do modelo é a aquisição da terra. Vimos anteriormente que o Termo Territorial Coletivo pressupõe a propriedade privada para existir, pois a terra é titulada sob o nome da organização comunitária constituída para administrá-la em nome dos moradores. Neste sentido, o cenário de irregularidade fundiária que caracteriza a realidade dos assentamentos informais nas cidades brasileiras se torna um grave entrave para a aplicação do instrumento. Portanto, a regularização fundiária destas áreas é fundamental para permitir a existência do TTC.

Buscou-se demonstrar na primeira parte deste trabalho que, a partir do marco normativo da lei 13.465/2017, houve uma mudança radical no modelo da 
regularização fundiária adotado no Brasil. O que era antes um modelo pautado pela proteção da posse se tornou uma política centrada na titulação individual da propriedade privada dos lotes. Paradoxalmente, este movimento também pode acabar abrindo novas possibilidades para a implementação do Termo Territorial Coletivo:

Como todo instrumento jurídico, marcado por disputas e contradições, enquanto este novo modelo de regularização fundiária [Lei 13.465/2017] traz prejuízos diretos à segurança da posse e garantia de direitos dos moradores de baixa renda, também traz possibilidades para a moldagem de um modelo de CLT [Community Land Trust], eficaz exatamente na garantia de direitos e da segurança da posse em populações vulneráveis. Esta contradição se opera na medida em que a ênfase na regularização dominial via propriedade privada plena, ao mesmo tempo em que abre os territórios irregulares para a atuação do mercado - que tende a promover a expulsão dos moradores mais pobres pela elevação do custo de vida - também permite que se estabeleçam as condições para o estabelecimento de um modelo de CLT visto que facilita e barateia os processos de regularização registral dos terrenos e/ou imóveis. (FIDALGO, 2018, p. 13)

Ao facilitar a transferência da propriedade em assentamentos informais, o novo marco normativo da regularização fundiária também parece abrir portas para a obtenção de terras pelo TTC, na medida em que possibilita a incorporação de terras antes excluídas. Esta escolha legislativa, apesar de atender primordialmente a demandas de mercado, pode ser apropriada e utilizada para facilitar a implementação do modelo, cujo objetivo é justamente o contrário: impedir a mercantilização da terra.

No entanto, a dinâmica de transferência de propriedade da Lei 13.465/2017 é pautada por uma lógica de titulação individual dos moradores, formando diversos proprietários individuais, sem trabalhar formas de propriedade coletiva. Por conta disso, seria preciso uma alteração legal para permitir a titulação em nome de uma organização comunitária, composta pelos próprios moradores, de forma a afirmar o caráter coletivo da terra e impedir que esta seja negociada individualmente. Uma outra possibilidade seria, após ocorrer a titulação individual dos moradores, estes cederem a terra em favor da pessoa 
jurídica constituída como proprietária da terra, o que dependeria do grau de envolvimento comunitário com o projeto (FIDALGO, 2018, p. 16).

Apesar de encontrarmos mecanismos na legislação vigente que podem viabilizar a implementação do Termo Territorial Coletivo, é inegável que o cenário ideal seria a formulação de uma legislação própria que regule o instituto. Esta previsão legal poderia vir no formato de um capítulo sobre o TTC a ser inserido em alguma lei já existente ou na proposição de uma lei própria que regulamente o modelo, o que seria mais vantajoso.

\subsection{Considerações Materiais}

Como vimos, do ponto de vista jurídico, já existem na legislação nacional os instrumentos necessários para trazer o modelo do Termo Territorial Coletivo para o Brasil, apesar de ser desejável que ele venha a ter uma regulamentação legal própria. No entanto, não é suficiente apresentar uma análise dos mecanismos legais que viabilizem sua implementação, é preciso compreender se o TTC é de fato uma ferramenta interessante para a proteção do direito à moradia no contexto urbano brasileiro, quais os benefícios que ele traria e os desafios que poderiam surgir. Em primeiro lugar, falaremos de alguns destes desafios

Uma primeira dificuldade clara para a plena instauração do modelo é o já comentado cenário de generalizada irregularidade fundiária que marca as cidades brasileiras, especialmente na realidade dos assentamentos informais. Uma premissa básica para que o instrumento venha a ser adotado é a formalização dos direitos fundiários de um território. Não há possibilidade de construção de um TTC em um terreno irregular, já que o modelo depende da propriedade privada para funcionar. Por conta disso, a regularização fundiária se torna um elemento fundamental deste processo: 
Como o CLT [TTC] pressupõe a propriedade privada, envolvendo inclusive seu desmembramento entre terreno e construções. A regularização fundiária se torna uma questão prejudicial do processo. Ou seja, não há que se falar em qualquer arranjo jurídico que viabilize um CLT no país sem que a área que abrigará o modelo esteja regularizada. (FIDALGO, 2018, p. 13)

Apesar de reconhecermos que, se a segurança da posse é um componente fundamental do direito à moradia adequada, a regularização fundiária é um direito, trata-se de um processo custoso e que depende de vontade política para ser executado. A irregularidade fundiária é uma realidade histórica no Brasil, e apesar de haverem ocorrido iniciativas pontuais em alguns territórios, ainda estamos muito distantes da completa superação deste problema. Desta forma, a implementação de um TTC fica refém da vontade do Poder Público de promover uma política de regularização fundiária efetiva.

Uma segunda dificuldade que não pode ser ignorada é a forte presença nos meios urbanos de grupos paralelos de controle territorial, como a milícia e o tráfico. Tratam-se de organizações que se apropriam de um território e passam a reivindicar o monopólio da exploração de atividades econômicas das mais diversas, exercendo um controle completo sobre os moradores e submetendo-os à sua vontade. Este fenômeno é especialmente grave no contexto da cidade do Rio de Janeiro, onde pesquisas estimam que cerca de 2,2 milhões de pessoas (ou $1 / 3$ da população da cidade), atualmente vivem sob a influência, direta ou indireta, da milícia (WERNECK, 2019).

A capacidade de organização e mobilização comunitária é profundamente limitada nos espaços dominados pela milícia, e, como vimos, o Termo Territorial Coletivo é um modelo que demanda a participação constante de todos os moradores. A governança comunitária é um elemento fundamental para o funcionamento adequado de um TTC, e bairros que vivem sob a lógica da milícia tem restrições bastante concretas para isto. Além disso, é preciso garantir que o modelo não seja apropriado por estas organizações e sofra uma subversão de seus princípios e objetivos, em prejuízo dos moradores. Neste sentido, territórios 
sob a influência de grupos de controle enfrentariam sérios obstáculos se decidissem adotar o instrumento.

Um outro problema é a própria lógica individual e proprietária que permeia nossa sociedade. Como vimos, o Termo Territorial Coletivo estimula uma nova forma de relação com o território, que rompe com o paradigma do domínio individual da terra e instaura uma dinâmica na qual toda uma comunidade é coletivamente dona de seu território. Apesar da autonomia individual ser assegurada pelo fato de que todo morador é proprietário de sua casa, é inegável que esta autonomia é limitada dentro do modelo TTC, diante da necessidade de se garantir que a moradia seja permanentemente acessível economicamente.

Além disso, as decisões sobre a administração do TTC e o planejamento territorial são sempre tomadas a nível coletivo. O pleno funcionamento do modelo depende de uma mobilização comunitária que coloque o interesse coletivo à frente do interesse individual, de forma a assegurar que a finalidade social do instrumento seja alcançada. Neste sentido, para ser implementado e vir a ser uma experiência de sucesso, é preciso que esta lógica individualista da propriedade seja pelo menos mitigada e traduzida para a construção de uma nova lógica, pautada por uma busca por aquilo que é comum.

Apesar das dificuldades encontradas, podemos identificar inúmeros benefícios que o modelo pode vir a trazer se implementado no contexto de comunidades informais Brasil. Em primeiro lugar, o Termo Territorial Coletivo estimula o desenvolvimento local. Dar a autonomia na gestão e uso da terra para a coletividade que nela vive permite a busca por melhorias efetivas para a comunidade, ganhando uma certa independência em relação ao Estado na perseguição do próprio desenvolvimento. Isto é bastante visível na experiência de Porto Rico com o Fideicomiso de la Tierra Caño Martín Peña, em que após a implementação do TTC surgiram diversas iniciativas comunitárias, como 
comitês para pensar a questão do lixo, saneamento, turismo, questão ambiental, transporte, entre outros.

Além disso, o próprio poder de barganha com o Poder Público é ampliado. Muitas vezes, intervenções públicas em favelas e outros territórios são formuladas e implementadas de cima para baixo, a partir de uma posição unilateral do governo, sem uma efetiva participação e força decisória da comunidade nas ações tomadas e destinação dos recursos. A partir do momento em que moradores de uma comunidade se tornam coletivamente proprietários de um vasto território, o diálogo com o Estado muda de patamar. A organização comunitária passa a ter uma voz e força de negociação muito maior, reivindicando seu protagonismo na administração do território que agora the pertence de fato.

No entanto, a principal potencialidade de uma implementação do Termo Territorial Coletivo no Brasil é a garantia de segurança da posse nos territórios populares. O modelo enfrenta processos de despossessão causados pela mercantilização da terra e a especulação imobiliária sobre os espaços, assegurando a permanência de comunidades em seus locais de origem. A terra é retirada do mercado e fica atrelada à sua finalidade de promover habitação acessível pela perpetuidade.

Esta característica do TTC se torna bastante relevante diante do atual momento da regularização fundiária do país, marcado pelo advento da Lei 13.465/2017, que institui uma política de regularização centrada na titulação individual da propriedade para moradores de áreas irregulares. Como vimos, este movimento tem o potencial de permitir a penetração do mercado imobiliário sobre territórios antes inacessíveis, correndo o risco de aumentar a insegurança da posse destes moradores diante da iminente valorização imobiliária. Este fenômeno é particularmente grave se considerarmos a realidade do Rio de Janeiro, na qual diversas favelas se encontram em áreas nobres da cidade, territórios sofrerão um processo forte de pressão para a compra dos terrenos, que 
a longo prazo pode resultar no próprio desaparecimento da comunidade tal como ela existe.

Diante deste momento, no qual tanto a irregularidade fundiária quanto a titulação individual trazem problemas, o Termo Territorial Coletivo surge como alternativa. Ele pode se tornar uma ferramenta eficaz para evitar a segregação territorial dentro das cidades, permitindo a permanência de famílias de baixa renda em áreas valorizadas. A construção de uma cidade mais diversificada, viva, menos refém dos interesses do mercado imobiliário que se manifestam de forma absolutamente desproporcional em relação aos interesses dos citadinos. Uma cidade que afirme o valor de uso da terra como superior ao seu valor de troca, que reconheça o território como garantidor da satisfação das necessidades básicas, em especial: o direito à moradia. Talvez essa seja a maior contribuição que o Termo Territorial Coletivo possa dar às cidades do Brasil. 


\section{CONCLUSÃO}

Podemos dizer que, antes de mais nada, o Termo Territorial Coletivo é um mecanismo de proteção da segurança da posse para populações de baixa renda. Seu objetivo principal é garantir a permanência das comunidades em seus locais de origem, evitando processos de remoção forçada tanto pelo Estado (cuja ameaça decorre da generalizada situação de irregularidade fundiária) quanto pelo mercado (fruto das pressões imobiliárias sobre terras valorizadas). Longe de ser um instrumento revolucionário, o TTC se cria e desenvolve sob a lógica da propriedade, mas busca afastar os efeitos negativos da mercantilização da terra para a moradia, através da gestão comunitária do território, que passa a pertencer a todos que nele residem de forma coletiva. A terra é retirada do mercado e fica atrelada à sua finalidade de garantir habitação.

Ainda que o TTC não rompa completamente com a lógica da propriedade privada, ele busca fomentar o desenvolvimento de uma nova forma de relação com a terra. Sua filosofia é afirmar a terra como herança comum, incapaz de ser apropriada individualmente e transformada em mercadoria. A terra pertence a todos que nela vivem, e deve satisfazer as necessidades de toda a comunidade. A partir do modelo TTC, é estimulada a formação de uma subjetividade coletiva, um etos que coloque a comunidade antes do indivíduo, que trabalhe para o bem comum e não para o interesse individual.

O instrumento também é capaz de apresentar uma alternativa ao problema da mercantilização da terra que não dependa exclusivamente do Estado. Como sabemos, o Estado não está de forma alguma imune às pressões mercadológicas. Muito pelo contrário, muitas vezes trabalha como facilitador de interesses particulares sobre o espaço urbano, atuando em sentido contrário da promoção do interesse público. Neste sentido, incentivar iniciativas de autogestão e fortalecimento comunitário podem ser maneiras efetivas de se proteger a 
segurança da posse e garantir moradia acessível em territórios propensos a sofrer pressões do mercado imobiliário.

No entanto, não é possível prever por completo a totalidade dos efeitos que o modelo pode vir a ter se for implementado no Brasil, especialmente na realidade das comunidades informais. É bastante provável que diversos problemas surjam, dificuldades sejam descobertas, impondo novos desafios à gestão comunitária do TTC. Em outras palavras, não há como garantir de antemão que a experiência vai dar certo, que efetivamente alcançará todos os seus objetivos. No entanto, diante da difícil situação da moradia e da questão urbana no país, precisamos estar dispostos a buscar alternativas, soluções criativas e diferentes para enfrentar as adversidades e contradições que permeiam nossas cidades.

Apesar de ter sido criado em um contexto diferente e distante do nosso, o Termo Territorial Coletivo pode vir a tornar-se um mecanismo eficaz e interessante para comunidades informais na realidade urbana brasileira. $\mathrm{O}$ instrumento se mostra particularmente relevante por conta do novo momento da regularização fundiária no Brasil, onde prioriza-se a titulação individual dos lotes através da transferência de propriedade, inserindo assim espaços antes excluídos no circuito imobiliário formal. Este movimento pode ocasionar uma valorização imediata da terra em determinadas comunidades, principalmente as existentes em áreas nobres da cidade, o que tornaria difícil a permanência de populações carentes nestes espaços, intensificando a segregação territorial dentro das cidades. Desta forma, experiências como a dos Termos Territoriais Coletivos, que resistem à mercantilização do território através da gestão coletiva da propriedade se tornam importantes medidas de efetivação do direito à moradia adequada. 


\section{REFERÊNCIAS BIBLIOGRÁFICAS}

ABREU, João Maurício. A moradia informal no banco dos réus: Discurso normativo e prática judicial. Revista Direito FGV, São Paulo, vol. 7, n. 2, p. 391 416, 2011.

ABREU, João Maurício. A construção histórica do modelo proprietário no Brasil: Uma hipótese sobre o direito à moradia. Revista Direito e Práxis, vol. 5, n. 8, p. 213-239, 2014.

ASSEMBLEIA GERAL DA ONU. Informe de la Relatora Especial sobre una vivienda adecuada como elemento integrante del derecho a un nivel de vida adecuado y sobre el derecho de no discriminación a este respecto. 2013. Resolução A/HRC/25/54. Disponível em: <https://documents-ddsny.un.org/doc/UNDOC/GEN/G14/118/49/PDF/G1411849.pdf?OpenElement>. Acesso em 28 de Julho de 2019

ASSEMBLEIA GERAL DA ONU. Right to adequate housing: Note by the Secretary-General. 2013. Resolução A/HRC/68/289. Disponível em:

$<$ https://documents-ddsny.un.org/doc/UNDOC/GEN/N13/421/84/PDF/N1342184.pdf?OpenElement> Acesso em 28 de Julho de 2019.

ALGOED, Lina; TORRALEZ, María E. Hernández. Essa Terra É Nossa! Vulnerabilização e Resistência em Favelas: Lições do TTC do Caño Martín Peña. Rio On Watch. Rio de Janeiro, 16 jul. 2019. Disponível em: <https://rioonwatch.org.br/?tag=serie-terra-e-nossa> Acesso em 28 de Julho de 2019. 
ALGOED, Lina; TORRALEZ, María E. Hernández; DEL VALLE, Lyvia Rodríguez. El Fideicomiso de la Tierra del Caño Martín Peña Instrumento Notable de Regularización de Suelo en Asentamientos Informales. 2018. Lincoln Institute of Land Policy. Disponível em: $<$ https://www.lincolninst.edu/sites/default/files/pubfiles/algoed_wp18la1sp.pdf >. Acesso em 28 de Julho de 2019.

BALDEZ, Miguel Lanzellotti. A luta pela terra urbana. Revista de Direito da Procuradoria Geral do Estado do Rio de Janeiro, Rio de Janeiro, n. 51, p. 7192, 1998.

BARROS, Ciro. Altair enfrenta a terceira remoção da vida pelas Olimpíadas. Apública: Agência de Reportagem e Jornalismo Investigativo. Rio de Janeiro, 21 jun. 2013. Disponível em: <https://apublica.org/2013/06/altair-enfrentaterceira-remocao-da-vida-pelas-olimpiadas/>. Acesso em: 16 de Novembro de 2019

BASSET, Ellen M. The Persistence of the Commons: Economic Theory and Community Decision on Land Tenure in Voi, Kenya. African Studies Quarterly. Volume 9, Issue 3. 2007. Disponível em:

<https://www.researchgate.net/publication/265286551_The_Persistence_of_th e_Commons_Economic_Theory_and_Community_DecisionMaking_on_Land_Tenure_in_Voi_Kenya>. Acesso em 28 de Julho de 2019.

CARTA AO BRASIL. Medida provisória $n^{\circ}$ 759/2016: A desconstrução da Regularização Fundiária no Brasil. Disponível em: $<$ https://terradedireitos.org.br/noticias/noticias/carta-ao-brasil-medida- 
provisoria-n-7592016-a-desconstrucao-da-regularizacao-fundiaria-nobrasil/22571>. Acesso em 28 de Julho de 2019.

COMITÊ DOS DIREITOS ECONÔMICOS, SOCIAIS E CULTURAIS DA ONU. Comentário Geral no 4: Artigo 11 ${ }^{o}$, Número 1 (Relativo ao Direito a Alojamento Adequado). 1991. Disponível em: <http://acnudh.org/wpcontent/uploads/2011/06/Compilation-of-HR-instruments-and-generalcomments-2009-PDHJTimor-Leste-portugues.pdf>. Acesso em 16 de Novembro de 2019.

COMITÊ DOS DIREITOS ECONÔMICOS, SOCIAIS E CULTURAIS DA ONU. Comentário Geral no 7: Artigo 11 $1^{\circ}$, Número 1 (O Direito a um Alojamento Adequado: Desalojamentos Forçados). $1997 . \quad$ Disponível em: $<$ http://acnudh.org/wp-content/uploads/2011/06/Compilation-of-HRinstruments-and-general-comments-2009-PDHJTimor-Leste-portugues.pdf> . Acesso em 16 de Novembro de 2019.

CONGRESSO EM FOCO. Governo publica medida provisória com regras para regularização fundiária urbana e rural. 23 de Dezembro de 2016. Disponível em:

<https://congressoemfoco.uol.com.br/especial/noticias/governo-publica-mpcom-regras-para-regularizacao-fundiaria-urbana-e-rural/>. Acesso em 28 de Julho de 2019.

COX, Wendell. How Much of the World is Covered by Cities? New Geography. 2010. Disponível em: <https://www.newgeography.com/content/001689-howmuch-world-covered-cities>. Acesso em: 28 de Julho de 2019

CRABTREE, Louise; MOORE, Nicole; PHIBBS, Peter; BLUNDEN, Hazel; SAPPIDEEN, Carolyn. Community Land Trusts and Indigenous communities: 
from strategies to outcomes. Australian Housing and Urban Research Institute. 2015. Disponível em: <https://www.ahuri.edu.au/_data/assets/pdf_file/0006/2220/AHURI_Final_R eport_No239_Community-Land-Trusts-and-Indigenous-communities-fromstrategies-to-outcomes.pdf>. Acesso em 16 de Novembro de 2019.

DAVIS, John Emmeus. Origins and Evolution of Community Land Trust in the United States. 2010. In: DAVIS, J. E. (Org). The Community Land Trust Reader. Disponível em: <https://www.lincolninst.edu/sites/default/files/pubfiles/thecommunity-land-trust-reader-chp.pdf> . Acesso em: 28 de Julho de 2019

DE SOTO, Hernando. O Mistério do Capital: Por que o Capitalismo dá Certo nos Países Desenvolvidos e Fracassa no Resto do Mundo. Tradução de Zaida Maldonaldo. 1. Ed. Rio de Janeiro: Record, 2001. 306p.

EMERJ. "A irregularidade no Brasil supera mais de 50\% dos imóveis", diz pesquisadora Rosangela Luft, em palestra sobre legislação fundiária. 2017. Disponível em <http://www.emerj.tjrj.jus.br/paginas/noticias_todas/direito-dacidade.html>. Acesso em 28 de Julho de 2019.

ENGELSMAN, Udi; ROWE, Mike; SOUTHERN, Alan. Community Land Trusts: A Radical or Reformist Response to The Housing Question Today?. ACME: An International Journal for Critical Geographies, 2016, 15 (3): p. 589615. Disponível em: <https://www.researchgate.net/publication/309292370_Community_Land_Tru sts_A_Radical_or_Reformist_Response_to_The_Housing_Question_Today>. Acesso em: 16 de Novembro de 2019 
FIDALGO, Tarcyla. Parecer Jurídico sobre Legislação Brasileira em Relação ao Instrumento TTC, Preparado para o Lincoln Institute of Land Policy. 2018. Disponível em <http://comcat.org/wp-content/uploads/2018/08/2018-04Parecer-juridico-TTC-por-Tarcyla-Fidalgo-LILP.pdf>. Acesso em 28 de Julho de 2019.

FERREIRA, Paulo Sérgio. As Lógicas por trás das Políticas de Regularização Fundiária: a Alteração de Paradigma pela lei 13.465/2017. Revista Direito da Cidade, UERJ, Rio de Janeiro, vol. 10, n. 3, p. 1449-1482, 2018. Disponível em: $<$ https://www.e-publicacoes.uerj.br/index.php/rdc/article/view/32040>. Acesso em 28 de Julho de 2019.

GOIS, Antônio. Economista cobra propriedade em favela: Para o peruano Hernando de Soto, falta de legalização é entrave para o desenvolvimento. Folha de São Paulo, São Paulo, 13 ago. 2001. Disponível em: <https://www1.folha.uol.com.br/fsp/brasil/fc1308200115.htm>. Acesso em 28 de Julho de 2019.

FUNDAÇÃO JOÃO PINHEIRO. Déficit habitacional no Brasil 2015. Fundação João Pinheiro, Diretoria de Estatística e Informações. - Belo Horizonte: FJP, 2018. Disponível em: <http://fjp.mg.gov.br/index.php/docman/direi-2018/871-6-serie-estatistica-einformacoes-deficit-habitacional-no-brasil-2015291118/file.>. Acesso em 28 de Julho de 2019.

FUNDAÇÃO JOÃO PINHEIRO. Déficit habitacional municipal no Brasil 2010. Fundação João Pinheiro. Centro de Estatística e Informações - Belo Horizonte, 2013.2 Disponível em: 
<http://fjp.mg.gov.br/index.php/docman/cei/deficit-habitacional/216-deficithabitacional-municipal-no-brasil-2010/file.>. Acesso em 28 de Julho de 2019.

GADELHA, Regina Maria. A Lei de Terras (1850) e a Abolição da Escravidão: Capitalismo e Força de Trabalho no Brasil do Século XIX. Revista de História da USP, $\quad$ n. 120, $1989 . \quad$ Disponível em: <http://www.revistas.usp.br/revhistoria/article/view/18599>. Acesso em: 16 de Novembro de 2019

GOMES, Orlando apud BAPTISTA, Bruno de Albuquerque. Direito Real de Superficie. 2001. Disponível em: <https://www.boletimjuridico.com.br/doutrina/texto.asp?id=2385>. Acesso em: 28 de Julho de 2019.

HARRINGTON, Catherine; SEAGRIEF, Rose. The Community Land Trust Handbook. National CLT Handbook, 2012. Disponível em: <https://d1ssu070pg2v9i.cloudfront.net/pex/carnegie_uk_trust/2016/02/pub145 5011611.pdf>. Acesso em: 16 de Novembro de 2019.

MAJCEN, Katja. O Crescimento do Movimento Global do TTC, Parte 4: França. RioOnWatch, Rio de Janeiro, 05 nov. 2019. Disponível em: <https://rioonwatch.org.br/?p=43857>. Acesso em: 16 de Novembro de 2019.

MARICATO, Ermínia. O Impasse da Política Urbana no Brasil. 1. ed. Petrópolis: Editora Vozes, 2011.

MENDONÇA, Rafael da Mota. A Transferência de Propriedade como Novo Modelo da Regularização Fundiária: a Legitimação Fundiária e a Legitimação 
de Posse. In: FERNANDES, Arícia Correias (Org.). Direito da Regularização Fundiária Urbana Sustentável. Juiz de Fora: Editar, 2018. P. 259-284.

NELSON, Tara. O Crescimento do Movimento Global do TTC, Parte 2: TTCs no Reino Unido-Solução Para a Crise Habitacional?. RioOnWatch, Rio de Janeiro, 20 out. 2019. Disponível em: <https://rioonwatch.org.br/?p=43751>. Acesso em: 16 de Novembro de 2019.

NEW URBAN AGENDA. United Nations Conference on Housing and Sustainable Urban Development (Habitat III). 20 out. 2016. Disponível em: <http://habitat3.org/the-new-urban-agenda/>. Acesso em 27 de Julho de 2019.

RIBEIRO, Luiz. Metade dos imóveis no país são irregulares, segundo ministério. Correio Braziliense, Rio de Janeiro, 28 jul. 2019. Disponível em: <https://www.correiobraziliense.com.br/app/noticia/brasil/2019/07/28/internabrasil,774183/imoveis-irregulares-no-brasil.shtml>. Acesso em 16 de Novembro de 2019.

ROLNIK, Raquel. As Favelas Como Espaço de Resistência. UrbFavelas: registros e reflexões do II Seminário Nacional Sobre Urbanização de Favelas, p. 08-11 - São Paulo: Publisher Brasil, 2017.

ROLNIK, Raquel. Guerra dos lugares: a Colonização da Terra e da Moradia na Era das Finanças. 2. Ed. São Paulo: Boitempo, 2019. 456p.

ROSENVALD, Nelson; FARIA, Cristiano Chaves de. Direitos Reais. $6^{a}$ edição. $2^{\mathrm{a}}$ triagem. Rio de Janeiro: Lumen Juris, 2009. 
SAULE JÚNIOR, Nelson. O Direito à Moradia como Responsabilidade do Estado Brasileiro. 1997. Instituto Pólis. Disponível em:

$<$ http://polis.org.br/publicacoes/o-direito-a-moradia-como-responsabilidadedo-estado-brasileiro/>

SOTTO, Debora. Redescobrindo o Direito de Superfície Através dos Community Land Trusts: Alternativas para a Realização do Direito à Moradia Adequada no Brasil. 2017. Disponível em:

<https://www.researchgate.net/publication/323548192_Redescobrindo_o_direi to_de_superficie_atraves_dos_Community_Land_Trusts_alternativas_para_a_ realizacao_do_direito_a_moradia_adequada_no_Brasil>. Acesso em 28 de Julho de 2019.

THADEN, Emily; ROSENBERG, Greg. Outperforming the Market: Delinquency and Foreclosure Rates in Community Land Trusts. Lincoln Institute of Land Policy. 2010. Disponível em: <https://www.lincolninst.edu/publications/articles/outperforming-market>. Acesso em 16 de Novembro de 2019.

UNITED NATIONS. 2018 Revision of World Urbanization Prospects. 2018. Disponível em: $<$ https://www.un.org/development/desa/publications/2018-revision-of-worldurbanization-prospects.html>

UN-HABITAT. Community Land Trusts: Affordable Access to Land and Housing. 2012. Disponível em:

$<$ https://unhabitat.org/books/community-land-trusts-affordable-access-to-landand-housing/>. Acesso em 28 de Julho de 2019 
VADOT, Alix. O Crescimento do Movimento Global do TTC, Parte 3: Bélgica, Onde Inovadoras Organizações Sociais Lideram o Movimento para Soluções Habitacionais. RioOnWatch, Rio de Janeiro, 27 out. 2019. Disponível em: <https://rioonwatch.org.br/?p=43799>. Acesso em: 16 de Novembro de 2019.

WERNECK, Afonso. Milícias chegam a 26 bairros do Rio e a outras 14 cidades do Estado. O Globo, Rio de Janeiro, 31 mar. 2019. Disponível em: $<$ https://oglobo.globo.com/rio/milicias-chegam-26-bairros-do-rio-a-outras-14cidades-do-estado-23563315>. Acesso em 16 de Novembro de 2019.

WORLD HABITAT AWARDS. Caño Martín Peña Community Land Trust. Disponível em: <https://www.world-habitat.org/world-habitat-awards/winnersand-finalists/cano-martin-pena-community-land-trust/>. Acesso em 28 de Julho de 2019.

BRASIL. Constituição (1988). Constituição da República Federativa do Brasil. Brasília, DF. Disponível em: <http://www.planalto.gov.br/ccivil_03/constituicao/constituicaocompilado.htm >. Acesso em: 28 de Julho de 2019.

BRASIL. Lei n ${ }^{\circ}$ 10.257, de 10 de Julho de 2001. Estatuto da Cidade. Disponível em: <http://www.planalto.gov.br/ccivil_03/leis/leis_2001/110257.htm>. Acesso em: 28 de Julho de 2019.

BRASIL. Lei $\mathrm{n}^{\circ}$ 10.406, de 10 de Janeiro de 2002. Código Civil Brasileiro. Disponível em: <http://www.planalto.gov.br/ccivil_03/leis/2002/110406.htm〉. Acesso em: 28 de Julho de 2019. 
BRASIL. Lei n 13.465 , de 11 de Julho de 2017. Regularização Fundiária Rural e Urbana. Disponível em: <http://www.planalto.gov.br/ccivil_03/_Ato20152018/2017/Lei/L13465.htm>. Acesso em: 28 de Julho de 2019.

BRASIL. Lei $\mathrm{n}^{\circ}$ 11.977, de 07 de Julho de 2009. Dispõe sobre o Programa Minha Casa Minha Vida - MCMV - e Regularização Fundiária em Assentamentos Urbanos. Disponível em: <http://www.planalto.gov.br/ccivil_03/_ato2007-2010/2009/lei/111977.htm>. Acesso em: 28 de Julho de 2019.

BRASIL. Medida Provisória n 2.220 , de 04 de Setembro de 2001. Dispõe sobre a CUEM. Disponível em: <http://www.planalto.gov.br/ccivil_03/MPV/2220.htm>. Acesso em: 28 de Julho de 2019.

BRASIL. Decreto-Lei $n^{\circ}$ 591, de 06 de Julho de 1992. Promulga o Pacto Internacional sobre Direitos Sociais, Econômicos e Culturais. Disponível em: <http://www.planalto.gov.br/ccivil_03/decreto/1990-1994/d0591.htm>. Acesso em: 28 de Julho de 2019.

BRASIL. Decreto-Lei $\mathrm{n}^{\circ}$ 271, de 28 de Fevereiro de 1967. Dispõe sobre Loteamento Urbano. Disponível em: <http://www.planalto.gov.br/ccivil_03/decreto-lei/del0271.htm>. Acesso em: 28 de Julho de 2019.

PORTO RICO. Lei no 489, de 24 de Setembro de 2004. Disponível em: <http://www.lexjuris.com/lexlex/leyes2004/lex12004489.htm>. Acesso em: 28 de Julho de 2019 
DECLARAÇÃO UNIVERSAL DOS DIREITOS HUMANOS. Assembleia Geral das Nações Unidas em Paris. 10 dez. 1948. Disponível em:

<https://nacoesunidas.org/wp-content/uploads/2018/10/DUDH.pdf>. Acesso em: 28 de Julho de 2019. 